\title{
Response and recovery of the Comanche carbonate platform surrounding multiple Cretaceous oceanic anoxic events, northern Gulf of Mexico
}

\author{
Ryan M. Phelps a, b, *, Charles Kerans ${ }^{\text {b, a }}$, Rui O.B.P. Da-Gama ${ }^{\text {, }}$ Jason Jeremiah ${ }^{\text {, }}$, \\ David Hull ${ }^{\mathrm{a}, \mathrm{b}}$, Robert G. Loucks ${ }^{\mathrm{a}}$ \\ ${ }^{a}$ Bureau of Economic Geology, Jackson School of Geosciences, The University of Texas at Austin, 10100 Burnet Rd., Bldg 130, Austin, TX 78758-4445, \\ United States \\ b Department of Geological Sciences, Jackson School of Geosciences, The University of Texas at Austin, University Station C1100, Austin, TX 78712-0254, \\ United States \\ ${ }^{c}$ Shell International E\&P, 200 N Dairy Ashford, Houston, TX 77079, United States
}

\section{A R T I C L E I N F O}

Article history:

Received 30 May 2014

Accepted in revised form 5 September 2014

Available online 6 January 2015

\section{Keywords:}

Cretaceous

Carbonate shelf

Oceanic anoxic event

OAE

Platform drowning

Carbon isotope

\begin{abstract}
A B S T R A C T
The ubiquity of carbonate platforms throughout the Cretaceous Period is recognized as a product of high eustatic sea-level and a distinct climatic optimum induced by rapid sea-floor spreading and elevated levels of atmospheric carbon-dioxide. Notably, a series of global oceanic anoxic events (OAEs) punctuate this time-interval and mark periods of significantly reduced free oxygen in the world's oceans. The best records of these events are often from one-dimensional shelf or basin sections where only abrupt shifts between oxygenated carbonates and anoxic shales are recorded. The Comanche Platform of central Texas provides a unique opportunity to study these events within a well-constrained stratigraphic framework in which their up-dip and down-dip sedimentologic effects can be observed and the recovery of the platform to equilibrium states can be timed and understood. Stable isotope data from whole cores in middle Hauterivian through lower Campanian mixed carbonate-siliciclastic strata are used to construct a 52-myr carbon isotope reference profile for the northern Gulf of Mexico. Correlation of this composite curve to numerous global reference profiles permits identification of several anoxic events and allows their impact on platform architecture and facies distribution to be documented. Oceanic anoxic events 1a, 1b, 1d, and 2 occurred immediately before, after, or during shale deposition in the Pine Island Member, Bexar Member, Del Rio Formation, and Eagle Ford Group, respectively. Oceanic anoxic event 3 corresponds to deposition of the Austin Chalk Group. Platform drowning on three occasions more closely coincided with globally recognized anoxic sub-events such as the Fallot, Albian-Cenomanian, and MidCenomanian events. This illustrates that the specific anoxic event most affecting a given carbonate platform varied globally as a function of regional oceanographic circumstances.

Using chemo- and sequence-stratigraphic observations, a four-stage model is proposed to describe the changing facies patterns, fauna, sedimentation accumulation rates, platform architectures, and relative sea-level trends of transgressive-regressive composite sequences that developed in response to global carbon-cycle perturbations. The four phases of platform evolution include the equilibrium, crisis, anoxic, and recovery stages. The equilibrium stage is characterized by progradational shelf geometries and coralrudist phototrophic faunal assemblages. Similar phototrophic fauna typify the crisis stage; however, incipient biocalcification crises of this phase led to retrogradational shelf morphologies, transgressive facies patterns, and increased clay mineral proportions. Anoxic stages of the Comanche Platform were coincident with back-ground deposition of organic-rich shale on drowned shelves and heterotrophic fauna dominated by oysters or coccolithophorids. Eustatic peaks of this stage were of moderate amplitude $(\sim 30 \mathrm{~m})$, yet relative sea-level rises were greatly enhanced by reduced sedimentation rates. In the
\end{abstract}

\footnotetext{
* Corresponding author. 600 N. Dairy Ashford Rd, PR 3050, Houston, TX, 77079, United States. Tel.: +12812933832.

E-mail addresses: Ryan.M.Phelps@conocophillips.com, phelpsrm@gmail.com (R.M. Phelps), ckerans@jsg.utexas.edu (C. Kerans), Rui.Da-Gama@shell.com (R.O.B.P. Da-Gama), Jason.Jeremiah@shell.com (J. Jeremiah), David.Hull@dvn.com (D. Hull), loucksb@beg.utexas.edu (R.G. Loucks).
} 
recovery stage, heterotrophic carbonate factories re-established at the shoreline as progradational ramp systems and sediment accumulation rates slowly increased as dysoxia diminished. Full recovery to equilibrium conditions may or may not have followed. Geochemical and stratigraphic trends present in the four stages are consistent with increased volcanism along mid-ocean ridges and in large-igneous provinces as primary drivers of Cretaceous OAEs and the resulting transgressive-regressive composite sequences.

(c) 2014 Elsevier Ltd. All rights reserved.

\section{Introduction}

Oceanic anoxic events (OAEs) documented from numerous time intervals in the latest Jurassic and Cretaceous periods were concomitant with significant perturbations to the global carbon cycle. Regardless of the mechanism invoked to trigger these events, it is clear that enhanced nutrient delivery to the marine realm dramatically increased surface-water primary productivity (Larson and Erba, 1999; Handoh and Lenton, 2003; Weissert and Erba, 2004; Mort et al., 2007; Elrick et al., 2009; Jimenez-Berrocoso et al., 2010). These perturbations are manifest in the stratigraphic record by the anomalous occurrence of organic-rich shale units deposited under dysoxic to anoxic conditions (Schlanger and Jenkyns, 1976; Jenkyns, 1980; Arthur and Sageman, 1994). Preservation of the resulting organic material was enhanced by bottomwater anoxia that extended from ocean basins onto continental shelves (Schlanger and Jenkyns, 1976; Weissert, 1989; MontoyaPino et al., 2010). Associated with these oceanographic events are the coincidental drowning of several carbonate platforms (Arthur and Schlanger, 1979; Groetsch et al., 1993; Föllmi et al., 1994; Weissert et al., 1998), decreases in nannofossil abundance (Erba, 1994; Mehay et al., 2009; Erba et al., 2010), and extinction/radiation events of radiolaria and foraminifera (Erbacher et al., 1996; Erbacher and Thurow, 1997; Parente et al., 2008). Thus it is evident that the causes and consequences of the OAEs rippled through the marine ecosystem and were catastrophic for most biologic communities.

Global correlation of the inter-basinal events is accomplished via vertical carbon isotope profiles derived from biostratigraphically constrained marine carbonate strata $\left(\delta^{13} \mathrm{C}\right)$ or the contained organic carbon $\left(\delta^{13} C_{\text {org }}\right.$ ) (Bralower et al., 1999; Scholle and Arthur, 1980). The diverse paleogeographic locations in which Cretaceous OAEs are documented illustrate their global extent, and include sites from the paleo-Tethys Ocean, Atlantic Ocean, Pacific Ocean, the western Gulf of Mexico, and the Western Interior Seaway of North America (Pratt et al., 1984; Weissert, 1989; Vahrenkamp, 1996; Menegatti et al., 1998; Bralower et al., 1999; Stoll and Schrag, 2000; Wilson and Norris, 2001; Jarvis et al., 2002; Price, 2003; Herrle et al., 2004; Locklair et al., 2004; Tsikos et al., 2004; Wendler et al., 2009; Jimenez-Berrocoso et al., 2010). High-resolution composite $\delta^{13} \mathrm{C}$ profiles for the Lower and Upper Cretaceous are developed from the Tethyan region and from English chalks, respectively (Weissert and Erba, 2004; Föllmi et al., 2006; Jarvis et al., 2006). These records place the OAEs within a larger chemostratigraphic context and offer valuable reference curves to which data from other regions can be correlated.

Using vertical $\delta^{13} \mathrm{C}$ profiles from mixed carbonate-siliciclastic subsurface cores of the Comanche Platform in south Texas, a near continuous composite carbon isotope curve is constructed for the middle Hauterivian through Campanian section of the northern Gulf of Mexico passive margin. The stratigraphic positions of OAEs $1 \mathrm{a}, 1 \mathrm{~b}, 1 \mathrm{~d}, 2$, and 3 are documented and detailed chemostratigraphic correlations to other global successions are provided. Regional anoxic events identified in other studies are expressed in the chemostratigraphy shown here, but do not necessarily correspond to shale units in the south Texas carbonate shelf. By establishing a >50-myr reference curve for the northern Gulf of Mexico, this study fills a void in the distribution of temporally-extensive data sets documenting the paleogeographic coverage of Tethyan Cretaceous OAEs (see Föllmi et al., 2006, fig. 6). Furthermore, new high-resolution data significantly enhance the global $\delta^{13} \mathrm{C}$ database for the middle to upper Albian interval following OAE $1 \mathrm{~b}$.

Prior establishment of a detailed sequence-stratigraphic framework (Phelps et al., 2014) allows regional sedimentologic analysis of each OAE and its effect on the shallow-marine carbonate platform. Integration of isotopic data with lithofacies cross-sections extending from the paleo-shoreline to shelf-margin enables twodimensional analysis of the demise and recovery of the carbonate system surrounding each anoxic event. Placement of the OAEs within a sequence-stratigraphic context provides greater insight into their driving mechanisms and the long-term response of carbonate depositional systems.

\section{Geologic setting and stratigraphy}

After Late Triassic to Early Jurassic rifting of the Pangean supercontinent and spreading of oceanic crust during the Middle to Late Jurassic (Salvador, 1991a; Sawyer et al., 1991), the northern Gulf of Mexico was transformed into a passive margin characterized by thermal subsidence (Winker and Buffler, 1988; Salvador, 1991b; Ewing, 2010). Following a Valanginian unconformity (Ewing, 2010), two mixed carbonate-siliciclastic rimmed-shelf systems, which are separated by Aptian ramp clinoforms, developed during the Hauterivian-Barremian and Albian stages (Rose, 1972; Loucks, 1976; Bebout, 1977; Scott, 1993; Phelps et al., 2014). Subtidal, mud-dominated carbonates and shales overlie the drowned Albian shelf and form the Cenomanian through lower Campanian interval (Scott et al., 1978; Dravis, 1980; Dawson, 1997; Scott et al., 2002; Lock and Peschier, 2006; Lock et al., 2007). Data shown here are from continuous whole cores acquired near the San Marcos Arch of the shelf interior and from the Lower Cretaceous shelf margins (Fig. 1). Terminal locations of the Sligo (HauterivianBarremian) and Stuart City (Albian) shelf margins formed a prominent shelf-slope break observable on regional seismic lines (Winker and Buffler, 1988; Tyrrell and Scott, 1989), and likely had shelf to basin relief on the order of hundreds of meters.

Phelps et al. (2014) presented a regional sequence-stratigraphic framework for the Comanche Platform by constructing a series of regional cross-sections from subsurface core descriptions, outcrop measured sections, and wireline log data. Published biostratigraphic data from the San Marcos Arch (Young, 1986), East Texas Basin (Jiang, 1989; Scott et al., 2002; Scott and Kerans, 2002) and shelf margins (Coogan, 1977; Waite et al., 2007) were combined with new nannofossil data to constrain regional correlations and ages of stratigraphic units. Sixteen transgressive-regressive depositional sequences of 1-3 myr duration were delineated and grouped into eight composite sequences of 3-14 myr duration based on the presence of regional unconformities, shelf-interior 


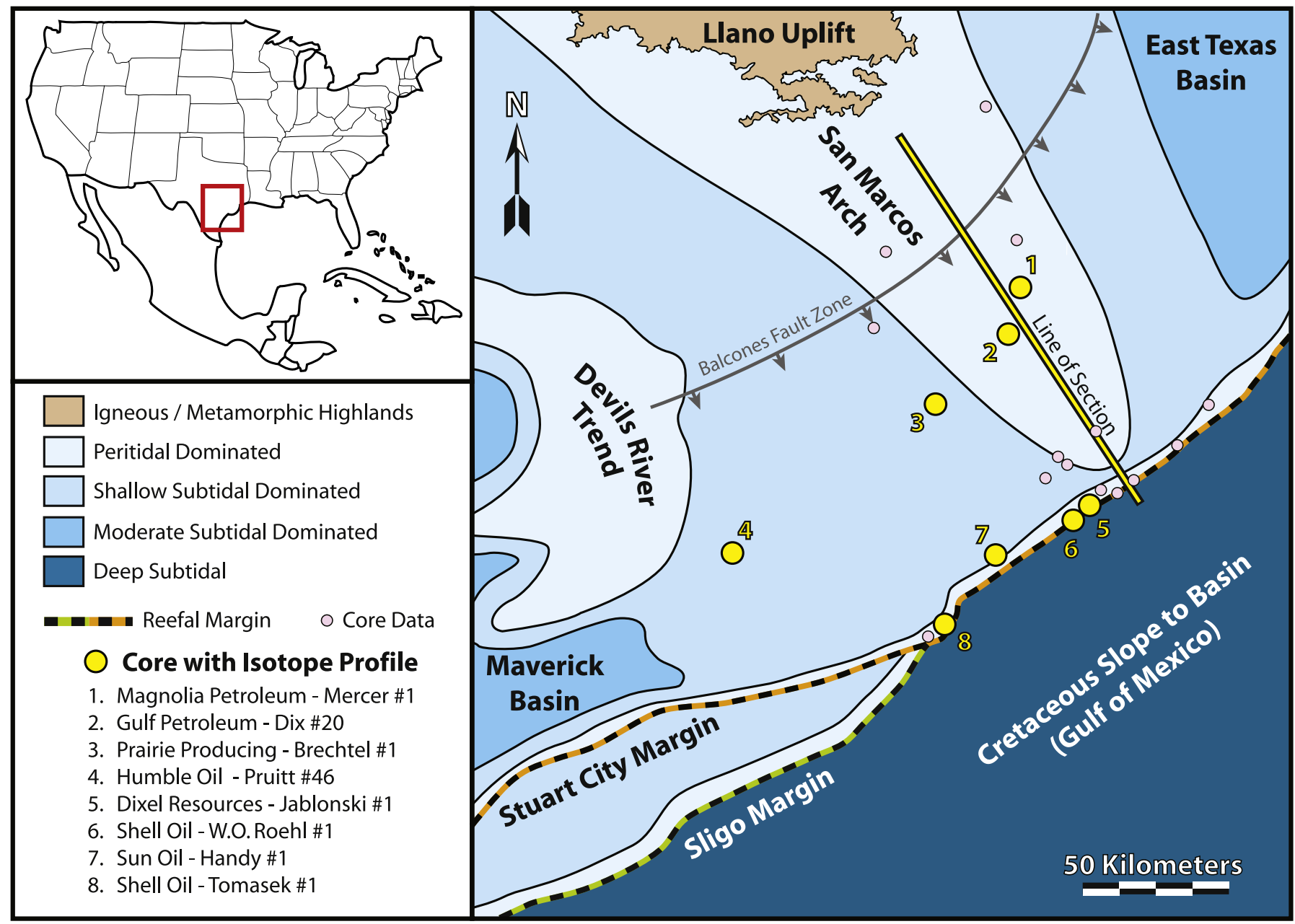

Fig. 1. Paleogeographic map of the south Texas Comanche platform in the northern Gulf of Mexico and location of cores used for the study.

facies tract offsets, and changes in shelf-margin trajectory. The composite sequences comprise three basin-wide supersequences that are greater than $15 \mathrm{myr}$ in duration with distinct carbonate platforms separated by platform drowning events.

\section{Stable isotope data acquisition methods}

Eight cores from the regional stratigraphic model were selected for stable isotope analysis based on core length, continuity, age, and location within the platform (Fig. 2). Cores were sampled at 0.15-2.5 m spacing as a function of relative sedimentation rate and temporal variability in the global $\delta^{13} \mathrm{C}$ curve. Powdered sample material was extracted using a $4.7 \mathrm{~mm}$ diameter drill-bit and a household drill. To obtain the original seawater $\delta^{13} \mathrm{C}$ value and prevent distortion of this signal by any single component, mud-dominated rock matrix materials consisting of terrigenous clay, carbonate micrite, fecal pellets, and finely-abraded skeletal fragments were targeted for sampling. In high-energy portions of the reefal shelf margin, no matrix micrite is present for tens of meters. Here, samples represent the bulk composition of skeletal grains present (rudists, corals, foraminifera, red algae, among others). Individual skeletal grains, macroscopic cements, and subaerial exposure zones were not sampled. Dolomite was avoided, although minor fractions $(<5 \%)$ were incorporated into some shelf-interior samples.

Powdered samples from the Shell Tomasek \#1 core were sent to the Analytical Laboratory for Paleoclimate Studies of the University of Texas at Austin for $\delta^{18} \mathrm{O}$ and $\delta^{13} \mathrm{C}$ analysis (Figs. 1, 2). Samples were prepared for analysis in a Kiel Device, dissolved with phosphoric acid at $70{ }^{\circ} \mathrm{C}$, and analyzed using a Thermo-Scientific MAT 253 mass-spectrometer. Results are reported relative to the Vienna Pee Dee Belemnite (VPBD) isotopic standard in per mil (\%o) notation. Average external precision is $0.04 \%$ for $\delta^{18} \mathrm{O}$ and $0.02 \%$ for $\delta^{13} \mathrm{C}(1 \sigma, n=37$, NBS-19). Long-term external precision based on NBS-19 is $0.05 \%$ for $\delta^{18} \mathrm{O}$ and $0.03 \%$ for $\delta^{13} \mathrm{C}(1 \sigma)$. Powdered samples from the remaining cores were sent to the Stable Isotope Laboratory of the University of Miami for $\delta^{18} \mathrm{O}$ and $\delta^{13} \mathrm{C}$ analysis using dissolution in a common acid bath of phosphoric acid at $90{ }^{\circ} \mathrm{C}$. Analysis was performed using a Finnigan-MAT 251 massspectrometer. Precision of results based on long-term replicate analysis of standards is $0.08 \%$.

\section{Stable isotope results}

\subsection{Diagenesis of primary $\delta^{13} \mathrm{C}$ values}

The $\delta^{13} \mathrm{C}$ values of well-preserved samples generally reflect the original composition of Cretaceous seawater at the moment of deposition. Changing primary $\delta^{13} \mathrm{C}$ ratios through time are a signal of variable global paleoceanographic conditions (Schlanger and Jenkyns, 1976; Scholle and Arthur, 1980). However, original stable isotope values of carbonate sediment are susceptible to opensystem diagenesis because of influxing meteoric or burial fluids 


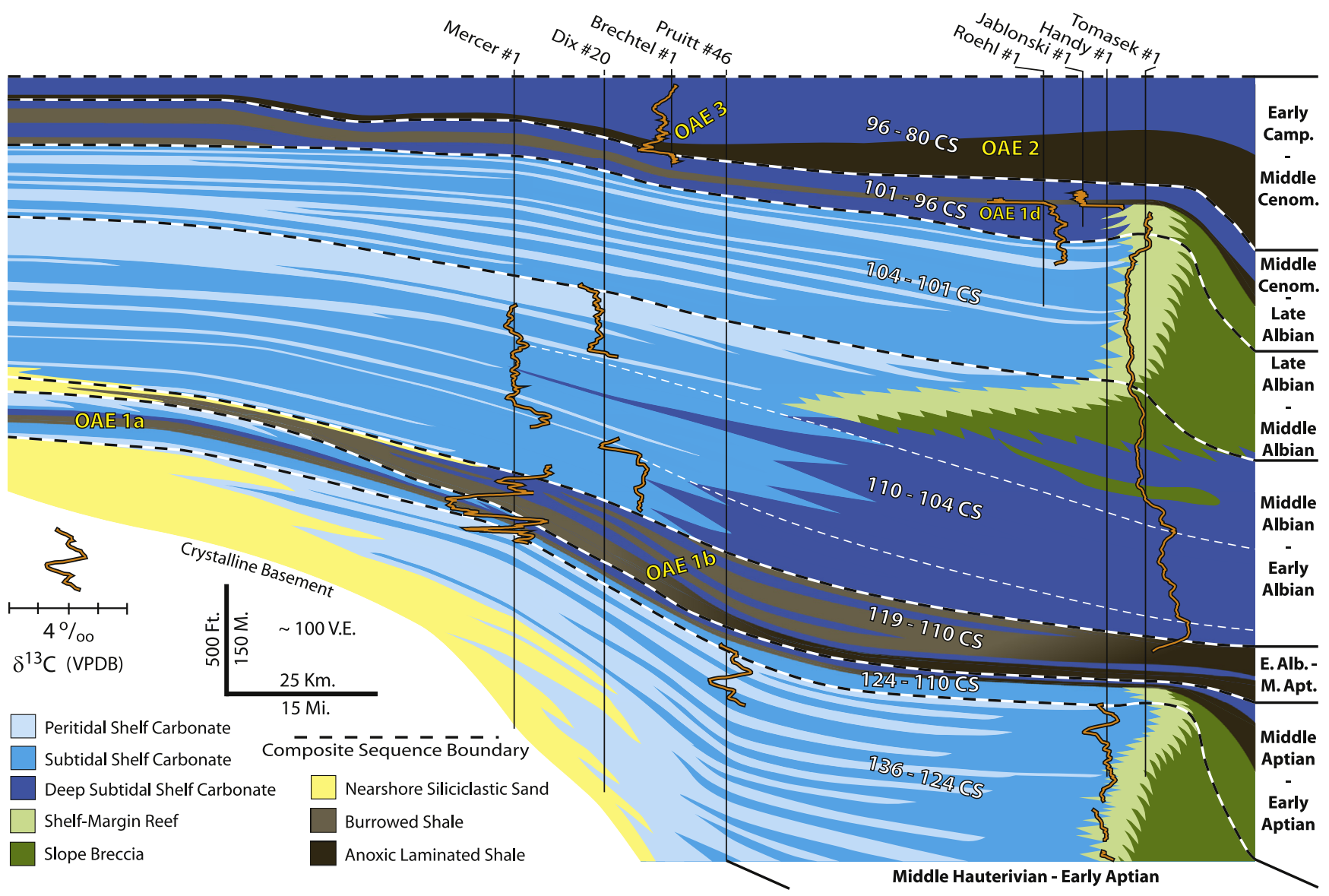

Fig. 2. The eight $\delta^{13} \mathrm{C}$ profiles in a simplified sequence-stratigraphic cross-section of the Comanche Platform. Data profiles represent 3 or 5 point moving averages.

and cementation of primary porosity (Dickson and Coleman, 1980; Allan and Matthews, 1982; Immenhauser et al., 2001; Moore, 2001). In addition, $\delta^{13} \mathrm{C}$ values may vary as a function of mineralogic variability, fractionation during skeleton secretion, and spatial variability in platform water $\delta^{13} \mathrm{C}$ values (Keith and Weber, 1965; Weber, 1965; Patterson and Walter, 1994; Steuber, 1996; Immenhauser et al., 2003; Swart and Eberli, 2005; Swart et al., 2009). Despite these processes, $\delta^{13} \mathrm{C}$ ratios of modern carbonate sediment show little facies-specific variability and no correlation to distance from the platform margin (Swart et al., 2009). Moreover, analysis of Valanginian-Huaterivian shallow-marine strata of the Alpine Tethys indicates $\delta^{13} \mathrm{C}$ values are independent of depositional environment, and variations among matrix micrite, individual grains, and bulk samples is usually less than $0.5 \%$ (Amodio et al., 2008). Regardless of their potential for early diagenesis and isotopic fractionation, shallow-marine carbonates are a viable source of data for construction of globally correlative carbon isotope profiles (Jenkyns, 1995; Vahrenkamp, 1996; Groetsch et al., 1998; Wissler et al., 2003; Huck et al., 2010; Vahrenkamp, 2010).

A cross-plot of $\delta^{18} \mathrm{O}$ versus $\delta^{13} \mathrm{C}$ data $(n=855)$ illustrates that approximately $98 \%$ of all samples cluster within a central field of values ranging from $-6-0 \% \delta^{18} \mathrm{O}$ and $0-5 \% \delta^{13} \mathrm{C}$ (Fig. 3). Many points located outside of this range are interpreted as diagenetically altered and have been discarded from moving averages for each core. Discarded data are from intervals with (1) diffuse burial dolomite in hemipelagic lime mud, (2) carbonate concretions, (3) reflux dolomite, or (4) abundant pyrite related to sulfate reduction of organic carbon. Each discarded sample is significantly deviant $(>1 \sigma)$ in comparison to the surrounding data with respect to $\delta^{18} \mathrm{O}$ or $\delta^{13} \mathrm{C}$, or is considerably lighter $(>1 \%$ ) than comparison reference curves.
Linear regression of all points indicates no covariance between $\delta^{18} \mathrm{O}$ and $\delta^{13} \mathrm{C}\left(R^{2}=0.05\right)$, thus diagenesis affecting $\delta^{18} \mathrm{O}$ ratios had little impact on the $\delta^{13} \mathrm{C}$ seawater values recorded by the carbonate sediment. This conclusion was also reached by Prezbindowski (1981) in a limited analysis of randomly selected samples from the Stuart City Formation.

Samples are derived from diverse environments and lithofacies of the platform (intertidal, shallow subtidal, reef, slope, flooded shelf) that likely experienced widely different diagenetic pathways. Regardless, excursions of coeval $\delta^{13} \mathrm{C}$ profiles in disparate settings are remarkably similar despite originating in different parts of the shelf (Fig. 2). Further, late Albian $\delta^{13} \mathrm{C}$ values of the Comanche Platform (1.9-3.7\%o) closely correspond to those of glassy planktic foraminifera from the Lower Saxony Basin (1.9-3.3\%o) (Erbacher et al., 2011). Microsampled $\delta^{13} \mathrm{C}$ values of fabric-retentive rudists, micrite, and early marine cements in multiple cores of the Sligo Formation vary from approximately $1.5-4.0 \%$ o, $1.5-3.75 \%$, and 2.5-3.5\%, respectively (Moldovanyi and Lohmann, 1984). These data are in agreement with the 1.9-4.0\% range of Sligo Formation matrix samples shown here. Statistical analysis, regional similarities between vertical profiles, and overlap in $\delta^{13} \mathrm{C}$ values with those of assorted internal and external samples indicate a reliable record of global $\delta^{13} \mathrm{C}$ secular variability is present in the south Texas dataset.

\subsection{Vertical isotope profiles}

Vertical oxygen and carbon isotope profiles are plotted against depth and shown with moving averages, core descriptions, and third-order composite sequence boundaries. Moving averages limit 


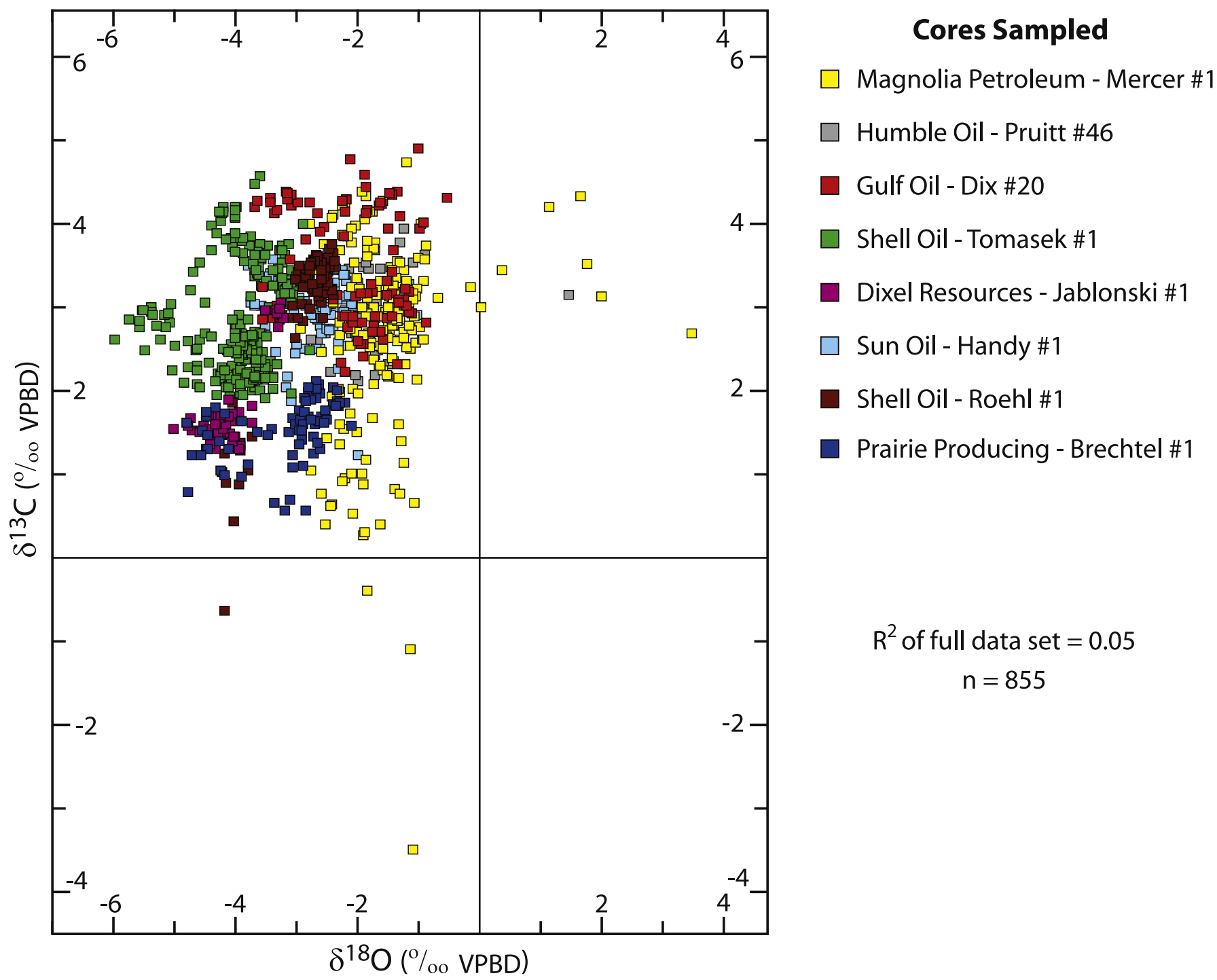

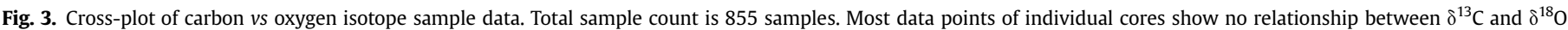
values, suggesting that diagenesis has not severely affected the primary $\delta^{13} \mathrm{C}$ values.

the influence of potentially unique sample compositions or diagenetic pathways. Three-point moving averages are used in muddominated, subtidal intervals that exhibit less scatter in vertical profile and presumably experienced closed-system diagenesis. Grain-dominated strata from intertidal, subtidal, and reefal settings exhibit greater scatter in vertical profile. These intervals experienced more complex diagenetic histories and data are shown with five-point moving averages. Open symbols denote data pairs with erratic $\delta^{18} \mathrm{O}$ or $\delta^{13} \mathrm{C}$ values excluded from the moving averages.

\subsubsection{Humble oil - Pruitt \#46 and Sun oil - Handy \#1}

The Pruitt \#46 and Handy \#1 cores together span 235 $\mathrm{m}$ of the Sligo Formation in the upper Hauterivian through lowermost Aptian (Figs. 1, 2, 4). Lithofacies in the Pruitt \#46 core are representative of shallow-subtidal to intertidal middle-shelf environments. The Handy \#1 core contains a progradational succession of shelf depositional environments over reefal platform-margin environments. Paleontologic age control via rudists is poor. Segments B1-B8 of Wissler et al. (2003) and C1-C2 of Menegatti et al. (1998) are tentatively identified. Multiple high-frequency cycles of relative sea level are present in each geochemical segment of both cores, yet cycle stacking patterns and vertical lithofacies proportions (i.e. subtidal versus intertidal) appear unrelated to segment boundaries. Multiple core gaps are present in the Hauterivian, but the Barremian and lower Aptian intervals are nearly continuous.

\subsubsection{Magnolia petroleum - Mercer \#1 and Gulf oil - Dix \#20}

The combined stratigraphy of the Mercer \#1 and Dix \#20 cores spans the lower Aptian through the middle Albian (Figs. 1, 2, 5, 6). Stratigraphic data and the $\delta^{13} \mathrm{C}$ curve from the Mercer \#1 core provide a detailed record of the middle-shelf response to OAEs 1a and $1 \mathrm{~b}$, as well as the intervening Fallot event. In the Mercer \#1 profile through the Pearsall Formation (Fig. 5), a negative excursion to $0.3 \% 0 \delta^{13} \mathrm{C}$ in clay-rich oyster biostromes is followed by an immediate shift back to $3.3 \% 0 \delta^{13} \mathrm{C}$ in the $5.6 \mathrm{~m}$ Pine Island Member. Nannofossil data show that this interval corresponds to OAE1a (Fig. 5). This shale member is overlain by molluscan grainstone and oncoid rudstone shoreface strata of the James Member. The uppermost James Member corresponds to the Fallot Event and consists of echinoid-oyster wackestones to mudstones with minor terrigenous clay fractions. Immediately overlying the James Member are approximately $23 \mathrm{~m}$ of brown, Planolites-burrowed shale of 


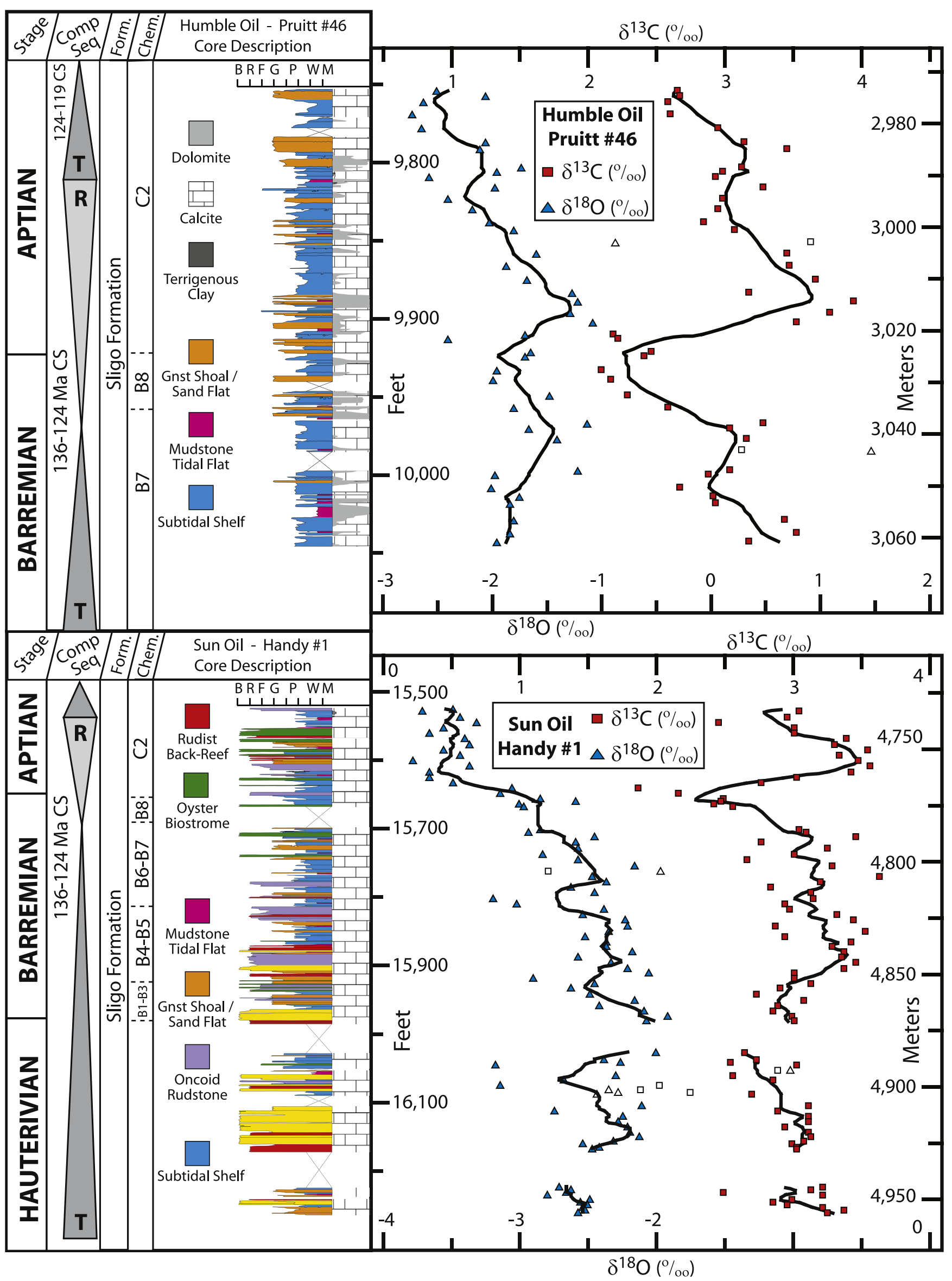

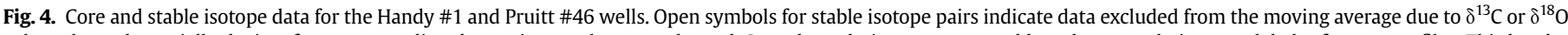

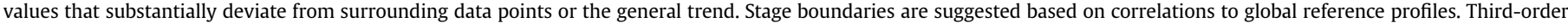
transgressive (T)/regressive (R) composite sequences (Comp Seq), lithostratigraphic formation units (Form.), and chemostratigraphic segments (Chem.) are also indicated. 


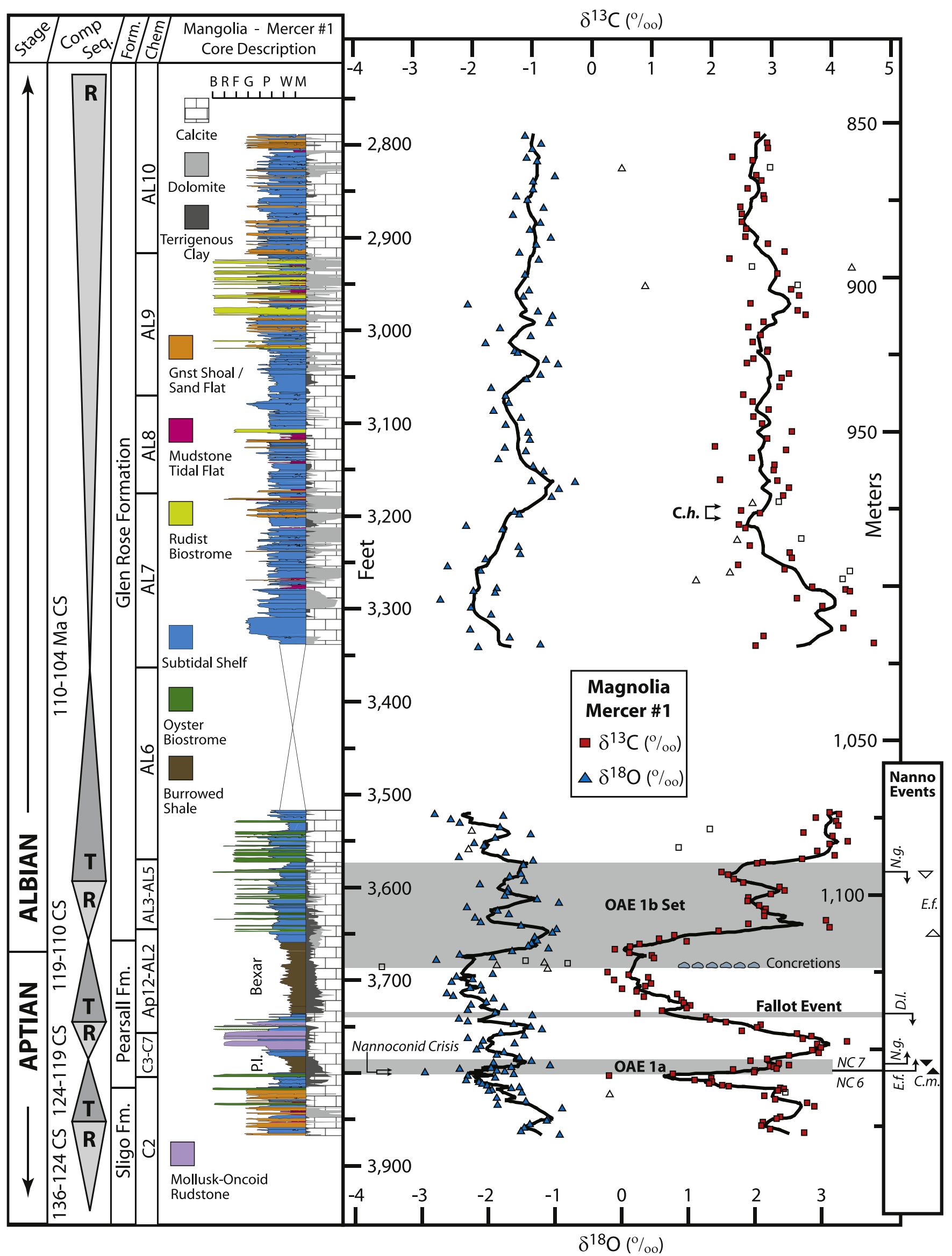

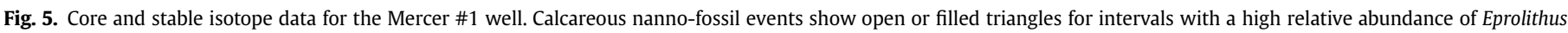

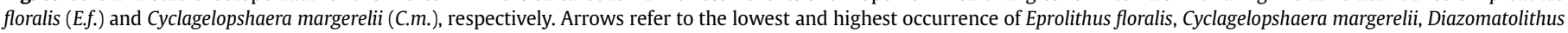

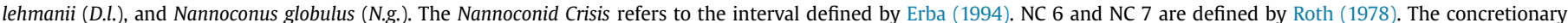

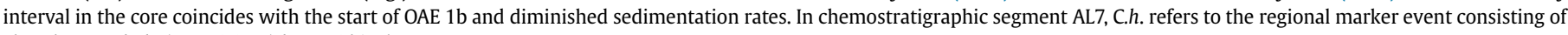
abundant Corbula (Eoursivivas) harveyi bivalves. 


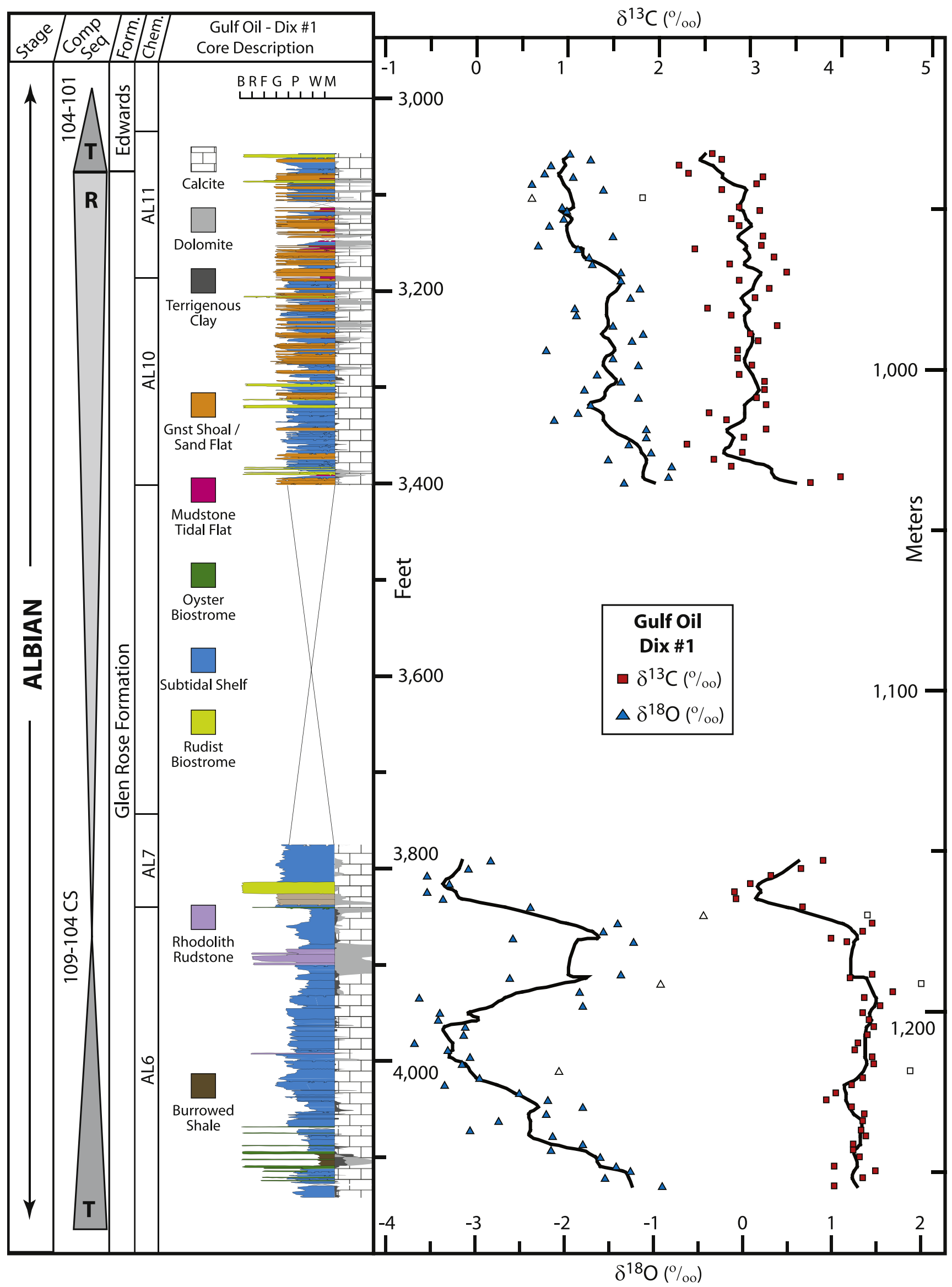

Fig. 6. Core and stable isotope data for the Dix \#20 well. 
the Bexar Member, which also contains ammonites and plant fragments. The uppermost $10 \mathrm{~m}$ of Bexar shale $\left(\sim 0.5-1.0 \%{ }^{13} \mathrm{C}\right)$ and the first $28 \mathrm{~m}$ of clay-rich, echinoid-oyster wackestone/packstone and oyster floatstone within the Glen Rose Fm $(\sim 2.1-3.2 \%$ $\delta^{13} \mathrm{C}$ ) are temporally equivalent to the OAE 1b set of Föllmi et al. (2006) (Fig. 5).

Younger intervals of the Mercer \#1 and Dix \#20 cores exceed $300 \mathrm{~m}$ of subtidal to intertidal section in the 110-104 Ma composite sequence. Varied lithologies and fauna of this interval are typical of the Comanche platform. Oysters and echinoids decrease in abundance up section while miliolid foraminifera, Orbitolina foraminifera, stromatoporoids, and rudist bivalves increase in abundance. Scatter in shelf-interior $\delta^{13} \mathrm{C}$ profiles increases during the highstand of the composite sequence due to more common occurrences of dolomite and inferred short-term $(\sim 20-40 \mathrm{ka})$ subaerial exposure.

\subsubsection{Shell oil - Tomasek \#1}

The Tomasek \#1 core includes the middle to upper Albian Stuart City shelf margin (Scott, 1990) and extends down into fore-reef and flooded shelf strata of the Glen Rose Formation (Figs. 1, 2, 7). The $\delta^{13} \mathrm{C}$ profile is nearly continuous for $612 \mathrm{~m}$ and exhibits a remarkably clean signature. The lower $10 \mathrm{~m}$ contain subtidal shelf mudstones and oncolitic wackestones that chemostratigraphically correspond to the end of OAE $1 \mathrm{~b}$. Above OAE $1 \mathrm{~b}$, approximately $200 \mathrm{~m}$ of globigerinid-bearing, oncolitic wackestones and subtidal shelf mudstones reveal a $\delta^{13} \mathrm{C}$ profile that decreases from $4 \%$ to $3 \%$ in a serrate manner. The remainder of the core contains rudist-rich lower slope breccias followed by prograding slope, reef, and backreef lithofacies of the Stuart City Formation with $\delta{ }^{13} \mathrm{C}$ values ranging from $1.9-3.1 \%$.

\subsubsection{Shell oil - W. Roehl \#1}

The Roehl \#1 core includes the uppermost portion of the Albian Stuart City margin and it extends into Planolites-burrowed shale of the lower Cenomanian Del Rio Formation (Figs. 1, 2, 8). Reefal and back-reef facies contain $\delta^{13} \mathrm{C}$ values from 3.0-3.7\%. The top $10 \mathrm{~m}$ of strata prior to drowning of the Stuart City margin near the AlbianCenomanian boundary contain multiple beds of burrowed gastropod-peloid wackestone and rudist back-reef bafflestone in a black, lime-mud-dominated matrix. Rudists in these units have thin valves and may have grown under stressed environmental conditions. Carbon isotope ratios of this interval decrease to $2.7 \%$ o and approximate the chemostratigraphic position of OAE $1 \mathrm{~d}$. The subsequent onset of burrowed shale deposition marks the AlbianCenomanian boundary event (Gale et al., 1996).

\subsubsection{Dixel resources - Jablonski \#1}

The Jablonski \#1 core completes the carbon isotope profile for the lower to middle Cenomanian. This interval encapsulates $11.5 \mathrm{~m}$ of globigerinid- and calcisphere-bearing burrowed shale in the Del Rio Formation and $10 \mathrm{~m}$ of globigerinid-rich subtidal-shelf mudstone/wackestone in the lower third of the Buda Formation (Figs. 1, 2, 8). The Del Rio Formation and equivalent units are early Cenomanian in age, as is the Buda Formation (Scott et al., 2002; Scott and Kerans, 2002). Carbon isotope values oscillate between 1.25 and $1.9 \%$. Several points are removed because of diagenetically related scatter in the $\delta^{18} \mathrm{O}$ data set. The signature of the Albian-Cenomanian boundary event at the base of the Del Rio Formation is less clear in this core and may be omitted at a surface of non-deposition.

\subsubsection{Prairie producing - Brechtel \#1}

The Brechtel \#1 core includes a nearly continuous section of middle Cenomanian through lower Campanian strata from the middle-platform setting, including the upper Buda Formation, the
Eagle Ford Group, and the Austin Chalk Group (Figs. 1, 2, 9). Each unit includes planktic foraminifera and calcispheres characteristic of a flooded shelf in a deep-subtidal setting. Within Thalassinoidesand Planolites-burrowed peloidal wackestones of the Buda Formation, $\delta^{13} \mathrm{C}$ values range from 1.5 to $2.1 \%$ before trending to progressively lighter values approaching $0.5 \%$ in the upper $3 \mathrm{~m}$ beneath the Eagle Ford Group. This contact is temporally equivalent to the Mid-Cretaceous Unconformity in many areas of the Gulf of Mexico (Buffler et al., 1980; Faust, 1990) and forms the top of the lower Cenomanian 101-96 Ma composite sequence. One and onehalf meters of planar-laminated black shale in the lower Eagle Ford Group are followed by $7.5 \mathrm{~m}$ of intercalated, planar-laminated shale and foraminiferal calcareous siltstone with bentonite horizons. Both lithofacies assemblages were deposited under anoxic to dysoxic conditions at the sediment-water interface and locally contain greater than 9 wt. \% TOC (Arthur and Sageman, 1994; Dawson, 1997). Calcareous nannofossils in the core highlight an upper Cenomanian through Turonian unconformity between the Eagle Ford and Austin Chalk groups; however, Turonian-age Eagle Ford Group strata are found in outcrops of central Texas (Jiang, 1989). The overlying bioturbated, argillaceous to glauconitic chalks of the Austin Chalk Group are Coniacian through early Campanian in age. Although burrowed and deposited under relatively more oxygenated conditions, Austin Chalk lithofacies contain up to 3.7\% TOC (Grabowski, 1995). Carbon isotopes values from the Eagle Ford and Austin Chalk groups are bound in the range of approximately $0.5-2 \%$.

\section{Correlation to reference profiles}

Reference $\delta^{13} \mathrm{C}$ profiles recording secular changes in the global carbon cycle are available for most stages of the Cretaceous, some of which are calibrated to numerical time scales (Scholle and Arthur, 1980; Jenkyns, 1995; Menegatti et al., 1998; Gale et al., 1996; Bralower et al., 1999; Erba et al., 1999; Stoll and Schrag, 2000; Wissler et al., 2003; Herrle et al., 2004; Weissert and Erba, 2004; Föllmi et al., 2006; Godet et al., 2006; Jarvis et al., 2006; Vahrenkamp, 2010; Giorgioni et al., 2012). Time-calibrated reference profiles are used as a basis for correlation of $\delta^{13} \mathrm{C}$ curves originally plotted against their respective stratigraphic sections. Stage boundaries and paleontologic zonations of planktic foraminifera, ammonites, and nannofossils provide pinning-points for comparison and scaling of $\delta^{13} \mathrm{C}$ curves from thickness to time representations. Excursions in $\delta^{13} \mathrm{C}_{\text {org }}$ profiles are assumed to mimic those of $\delta^{13} \mathrm{C}$ profiles derived from carbonate material; however, their absolute values and magnitudes significantly differ (Kump and Arthur, 1999).

\subsection{Hauterivian - Barremian isotope profiles}

The compiled profile of Föllmi et al. (2006) from the Vocontian Trough in the northern Tethys is used as the time-calibrated reference curve for the Hauterivian-Barremian interval (Fig. 10). Secondary reference profiles are from the Cismon Apticore of the central Tethys (Erba et al., 1999) and from Resolution Guyot of the mid-Pacific (Jenkyns, 1995).

A concave-right $\delta^{13} \mathrm{C}$ trend straddles the Hauterivian-Barremian boundary and is present in all data excluding the Vocontian Trough (Fig. 10). This signature spans 3 myr and may be characteristic of the stage boundary outside of the northern Tethys. Excluding the Vocontian Trough data, the Barremian profile from south Texas is consistent with the reference profiles in segments B1-B3 and $\mathrm{B} 6-\mathrm{B} 8$. Correlation in segments B4-B5 is tenuous and chemostratigraphic trends are generally inconsistent. A prominent negative excursion with amplitude ranging from $0.8-2.5 \%$ is associated 


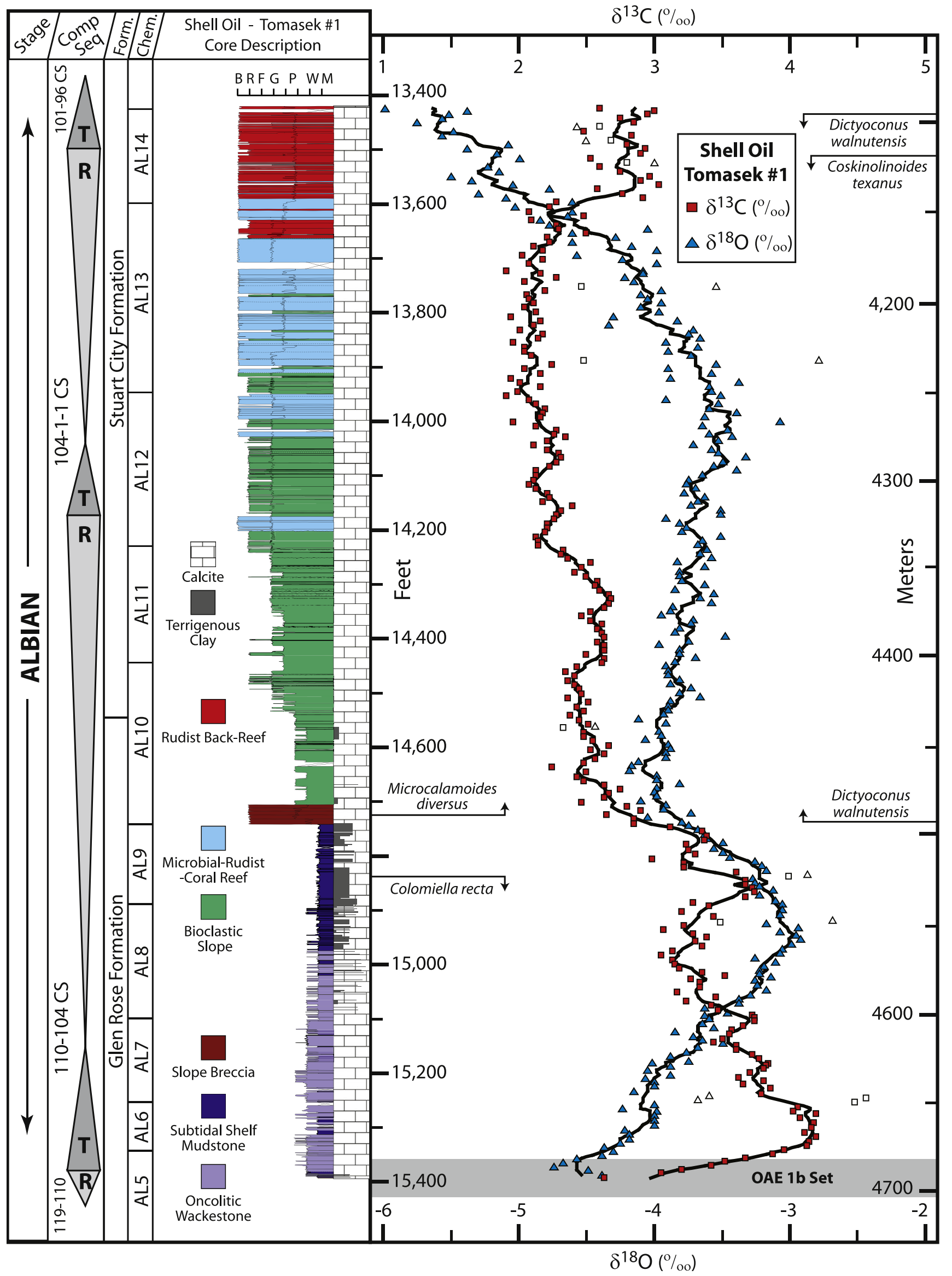

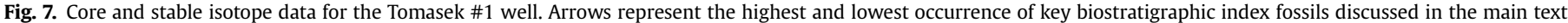




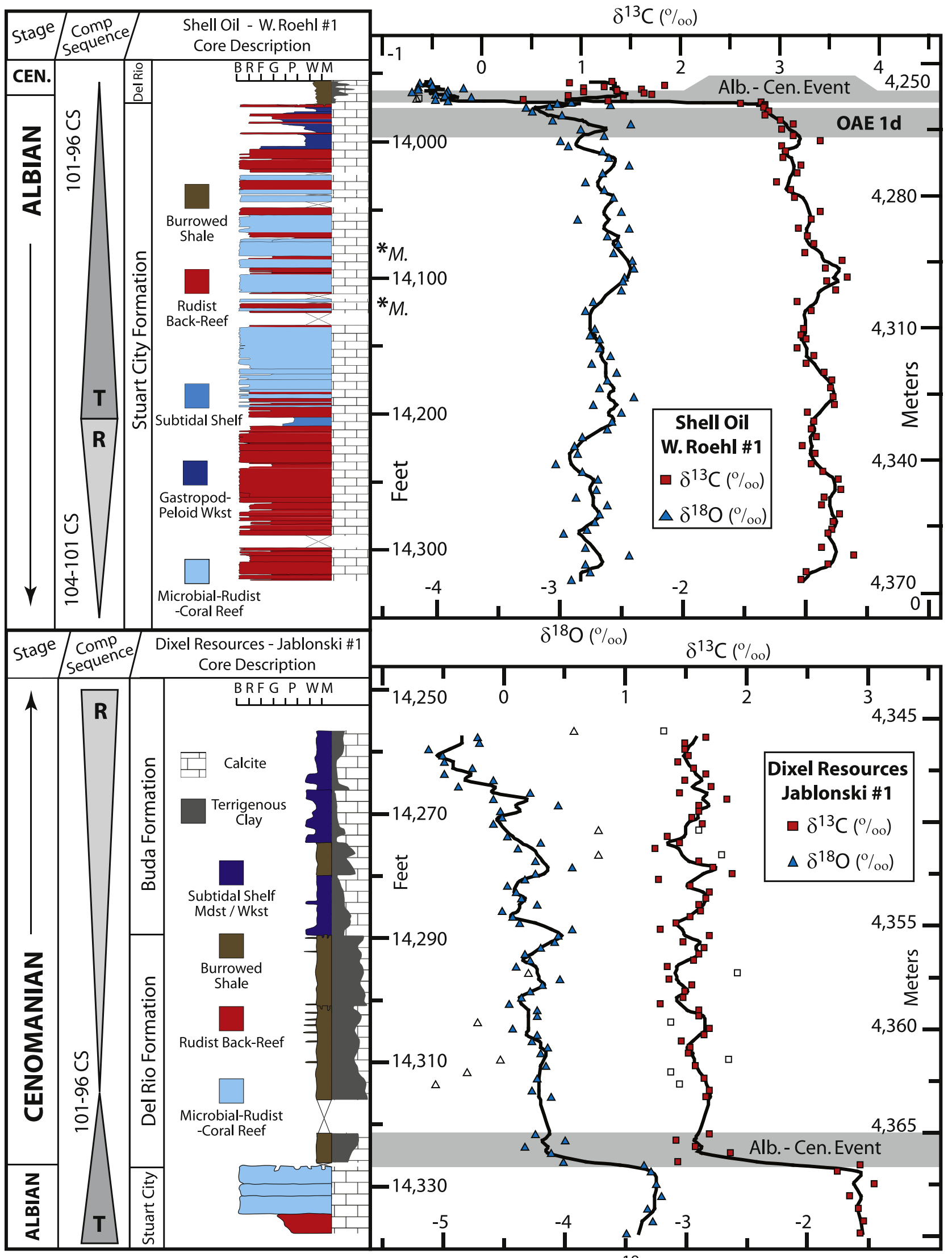

$\delta^{18} \mathrm{O}(\%)$

Fig. 8. Core and stable isotope data for the Roehl \#1 and Jablonski \#1 wells. The late Albian rudist, Mexicaprina sp. ( ${ }^{*} \mathrm{M}$.), provides some biostratigraphic control. 


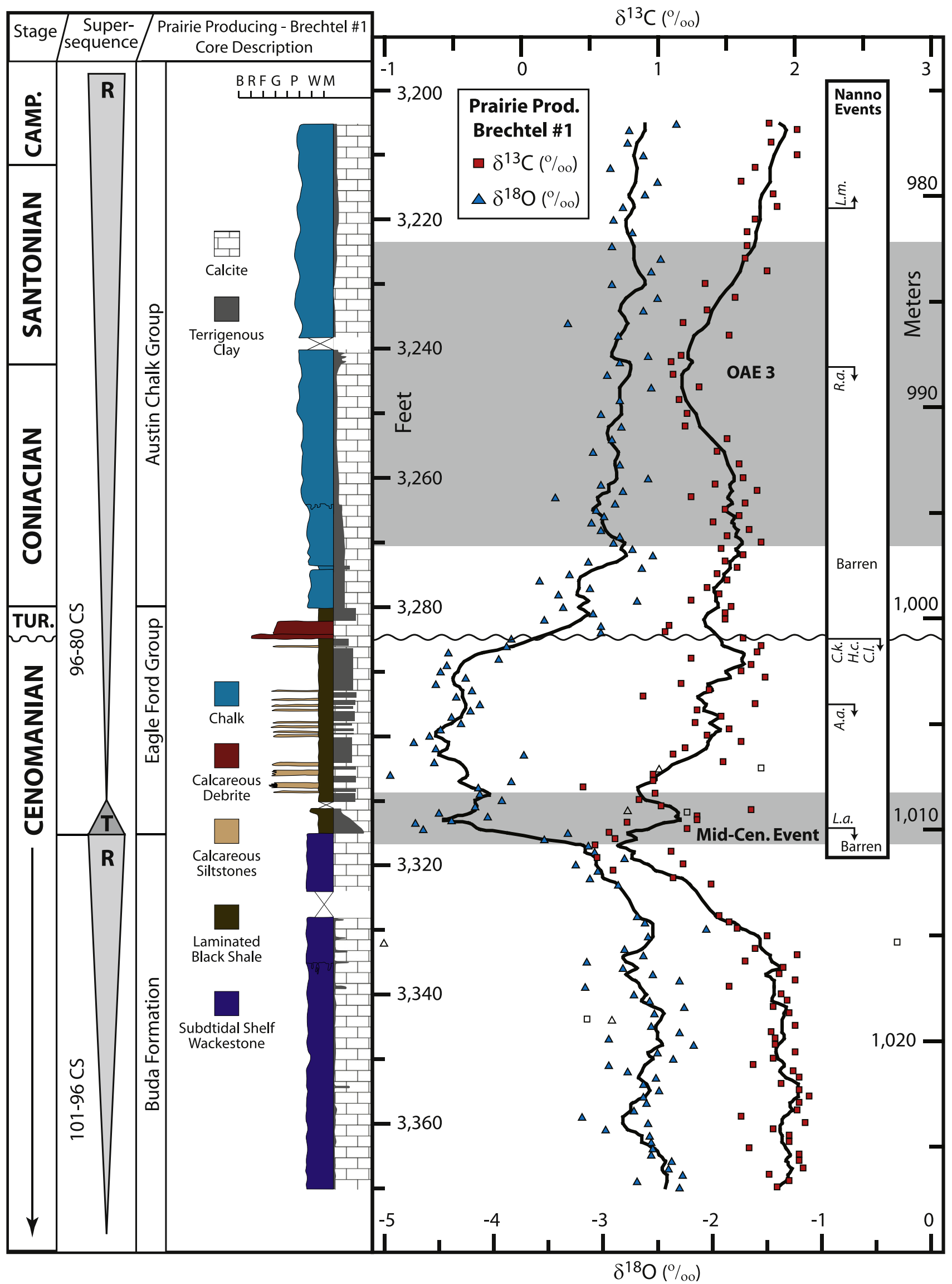

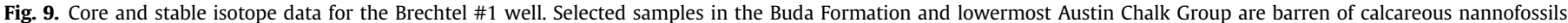

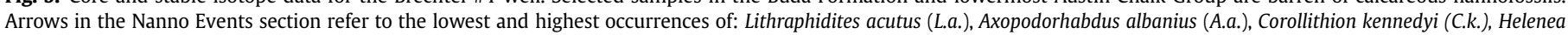

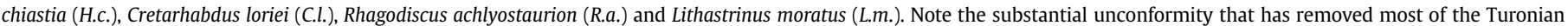
section and the record of OAE 2 at this location. 


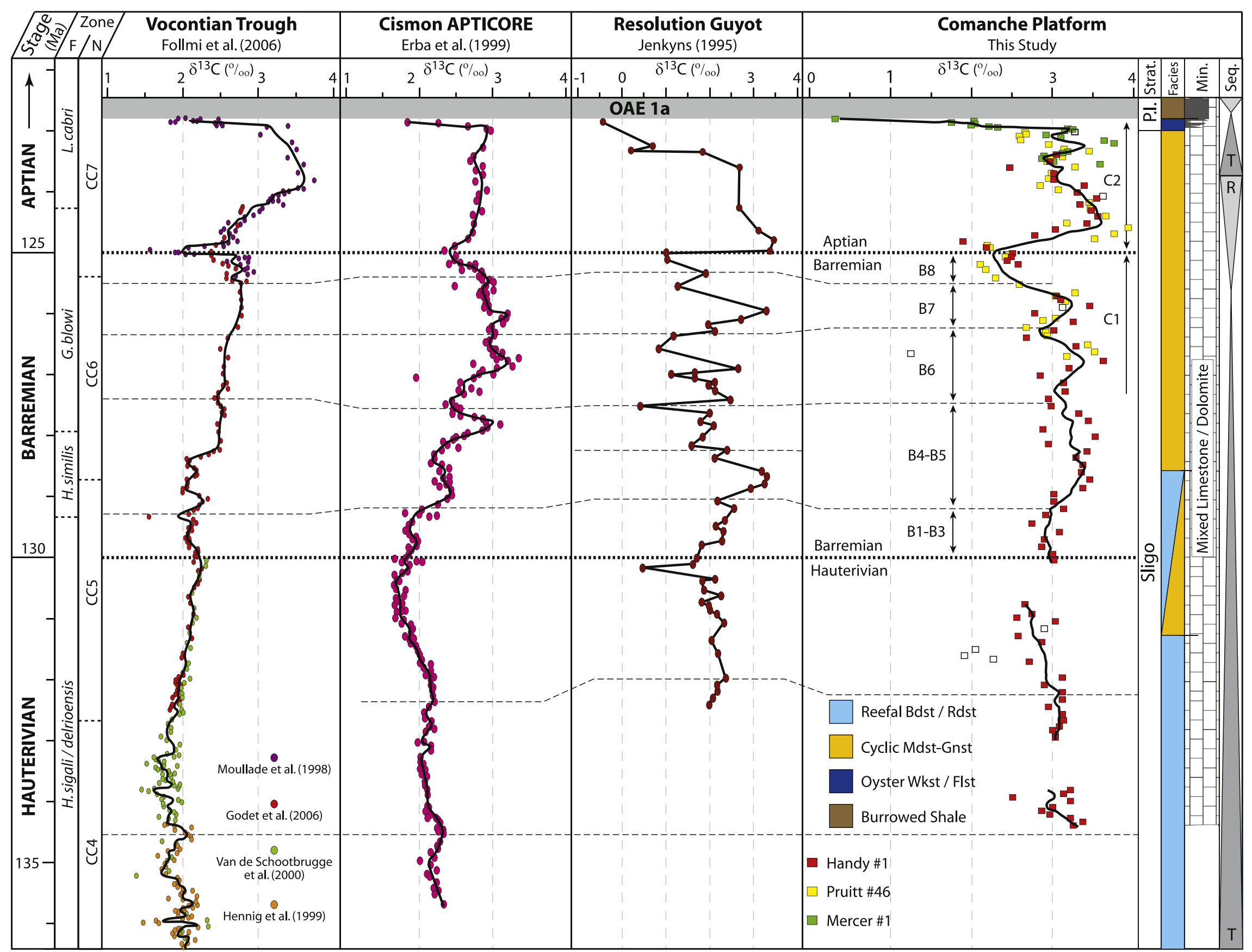

Fig. 10. Correlation of Comanche Platform $\delta^{13} \mathrm{C}$ data to Hauterivian and Barremian reference profiles. Segments B1-B8 and C1-C2 are from Wissler et al. (2003) and Menegatti et al. (1998), respectively 
with the Barremian-Aptian stage boundary ( $\mathrm{C} 1-\mathrm{C} 2$ transition) and is well defined in all records.

The broad character and excursions of the Vocontian Trough composite profile are generally dissimilar to those of the Cismon, Resolution Guyot, and Comanche Platform data sets during the Hauterivian and Barremian stages. As discussed at length by Föllmi et al. (2006), this dissimilarity may be the result of changing nutrient levels, modes of carbonate sediment production (heterozoan $v$ s photozoan), and dominant mineralogy (Godet et al., 2006) in the north Tethyan margin. Alternatively, disparate sedimentation rates between the regions could account for the differences (Wissler et al., 2003). South Texas data somewhat conform to the Cismon Apticore record in the central Tethys but best match the profile from Resolution Guyot in the mid-Pacific. Greater similarity between Comanche Platform and Resolution Guyot $\delta^{13} \mathrm{C}$ profiles may reflect the consistent photozoan faunal assemblages and primary aragonite/calcite ratios at those sites.

\subsection{Aptian isotope profiles}

Secular $\delta^{13} \mathrm{C}$ changes in the Aptian (Fig. 11) are constrained in the Vocontian Trough by data with centimeter-scale sample spacing and high-resolution biostratigraphy (Moullade et al., 1998; Herrle et al., 2004; Föllmi et al., 2006). Additional reference profiles are available from the Shu'aiba Formation of the southern Tethys (Vahrenkamp, 2010) and from hemipelagic sediments of the western Gulf of Mexico (Bralower et al., 1999). Segments C2-C8 (Menegatti et al., 1998) and Ap6-AL6 (Herrle et al., 2004) are used for correlation (Fig. 11). In comparison to the reference curves, data from the Comanche Platform are widely spaced through much of the Aptian, yet many chemostratigraphic segments are generally identifiable.

Lowermost Aptian strata on the Comanche platform include cyclic, subtidal to intertidal carbonates in the regressive portion of the 136-124 Ma CS and the transgressive portion of the 124-119 Ma CS (upper Sligo Formation). Terrigenous clay proportions increase upward in segment $\mathrm{C} 2$ and preceded the onset of OAE 1a by approximately $2.5 \mathrm{~m}$ or $500 \mathrm{ka}$. This clay increase occurred during the nannoconid crisis of the NC6 zone (Roth, 1978; Erba, 1994). This interval displays a negative excursion from $3.2 \%$ to $0.3 \%$. At the time, skeletal-oyster wackestone/packstone and oyster biostromes spread across the shelf. The trough of the excursion at segment $\mathrm{C} 3$ is in a reworked oyster biostrome with a clay-rich matrix. Deposition of Planolites-burrowed shale in the Pine Island Member ensued during segments C4-C6 of the NC7 zone. These segments of OAE 1a coincide with a local acme of Cyclagelosphaera margerelii, as well as the Niveau Goguel (Herrle et al., 2004) and Livello Selli events (Arthur et al., 1990; Erbacher and Thurow, 1997). Cyclagelosphaera margerelii has been shown resistant to excessive nutrients and prospered in conditions of bottom-water anoxia (Lees et al., 2006). Maximum flooding of the 124-119 Ma supersequence coincides with OAE 1a. Shale deposition and drowning of the Comanche Platform during OAE 1a is congruent with the response of northern Tethyan platforms (Föllmi et al., 1994; Weissert et al., 1998; Wissler et al., 2003). Termination of carbonate sedimentation in the Gulf of Mexico suggests that time-equivalent Lithocodium-Bacinella blooms in the Shu'aiba and Adriatic platforms (Vahrenkamp, 1996, 2010; Groetsch et al., 1998; Immenhauser et al., 2005; Huck et al., 2010; Rameil et al., 2010) were a sedimentary response confined to the central and southern Tethys.

Following OAE 1a, carbonate sedimentation resumed with deposition of oyster wackestones, oncoid rudstones, and molluscan grainstones in the highstand of the 124-119 Ma CS. Nannofossil assemblages increase in diversity upward until segments
Ap10-Ap11. At this level, the Fallot event (Friedrich et al., 2003) is present in all four comparison profiles and marks the second drowning episode on the Comanche Platform. The connection between platform drowning and the Fallot event indicates this environmental perturbation not only caused elevated rates of organic carbon burial in the Gulf of Mexico, Vocontian Basin, and eastern Pacific (Bralower et al., 1999; Friedrich et al., 2003), but also substantially disrupted shallow-marine ecosystems.

Shale deposition in the Bexar Member transpired during segments Ap12-AL2 following the Fallot event. The Jacob, Killian, and Paquier events of the Aptian-Albian OAE $1 \mathrm{~b}$ set are equivalent to the upper Bexar shale interval, although limited carbonate sedimentation resumed prior to the Leenhardt event (Figs. 2, 5, 11). Maximum flooding of the 124-119 Ma CS at the start of OAE 1b is manifest by a 2-m-interval with fractured calcite and chert concretions, possibly indicative of condensed sedimentation rates. Isotope values of matrix sediment in this interval range from $-3.51 \%$ to $-0.40 \% \delta^{13} \mathrm{C}$ (Figs. 5,11 ). These values are far lower than any comparable reference profile and likely reflect diagenesis. At this level, $C$. margerelii reappears. Eprolithus floralis exhibits a relative acme in the latter stages of OAE $1 \mathrm{~b}$. This acme may have occurred during a biocalcification crisis in which other calcareous nannofossils were not present or were dissolved, whereas E. floralis was resistant to acidic conditions (Bralower, 1988). Prediscophaera columnata, which marks the base of zone NC8, was not found in the south Texas cores and leaves some ambiguity in the stratigraphic correlation to reference profiles.

Lower to middle Aptian excursions in the north Tethyan Vocontian Trough data (Föllmi et al., 2006) are replicated closely by the Comanche Platform curve and other profiles (Bralower et al., 1999; Vahrenkamp, 2010). The upper Aptian to lowermost Albian character of the $\delta^{13} \mathrm{C}$ curve in segments AP15-AL2 is poorly defined relative to the Vocontian Trough data, with no positive excursions observed in segments AP15 and AL1 at the Jacob and Killian levels. The resolution of the Comanche Platform curve is poor in these intervals and clearly is affected by local diagenesis and concretion precipitation. In contrast, the occurrence of positive excursions in the basal Albian segments AL3, AL4, and AL6 matches those observed in the reference profiles. However, the magnitude of those excursions varies among the four profiles, suggesting local diagenetic or oceanographic overprints (platform vs basinal water) may be a factor in one or more locations.

\subsection{Albian isotope profiles}

Reference profiles for the Albian include those from the Apennine Mountains of the western Tethys (Giorgioni et al., 2012), Resolution Guyot (Jenkyns, 1995), northern Mexico (Scholle and Arthur, 1980; Bralower et al., 1999), the Nahr Umr Formation of Oman (Immenhauser et al., 2001), and Blake Nose in the western Atlantic (Wilson and Norris, 2001). Correlations are hampered by the lack of a time-calibrated $\delta^{13} \mathrm{C}$ reference curve (Fig. 12). Nonetheless, ages published for the Blake Nose profile and the Nahr Umr Formation (Immenhauser et al., 2001; Immenhauser and Scott, 2002) provide some time constraints and foram zonations are provided in Giorgioni et al. (2012). Although the data from Oman have been extensively overprinted by subaerial exposure surfaces, the broader trends created by successive samples appear consistent with other data sets. Above the basal Albian Leenhardt level, remaining Albian data from pelagic successions in the Apennines exhibit approximately $1.2 \%$ variation in value and show muted character. Other profiles show approximately $1.5-2.1 \%$ variation through the same interval. Further, geographically similar profiles from northern Mexico and the Comanche Platform show a negative drift through the Albian, whereas this drift is minimal in the 


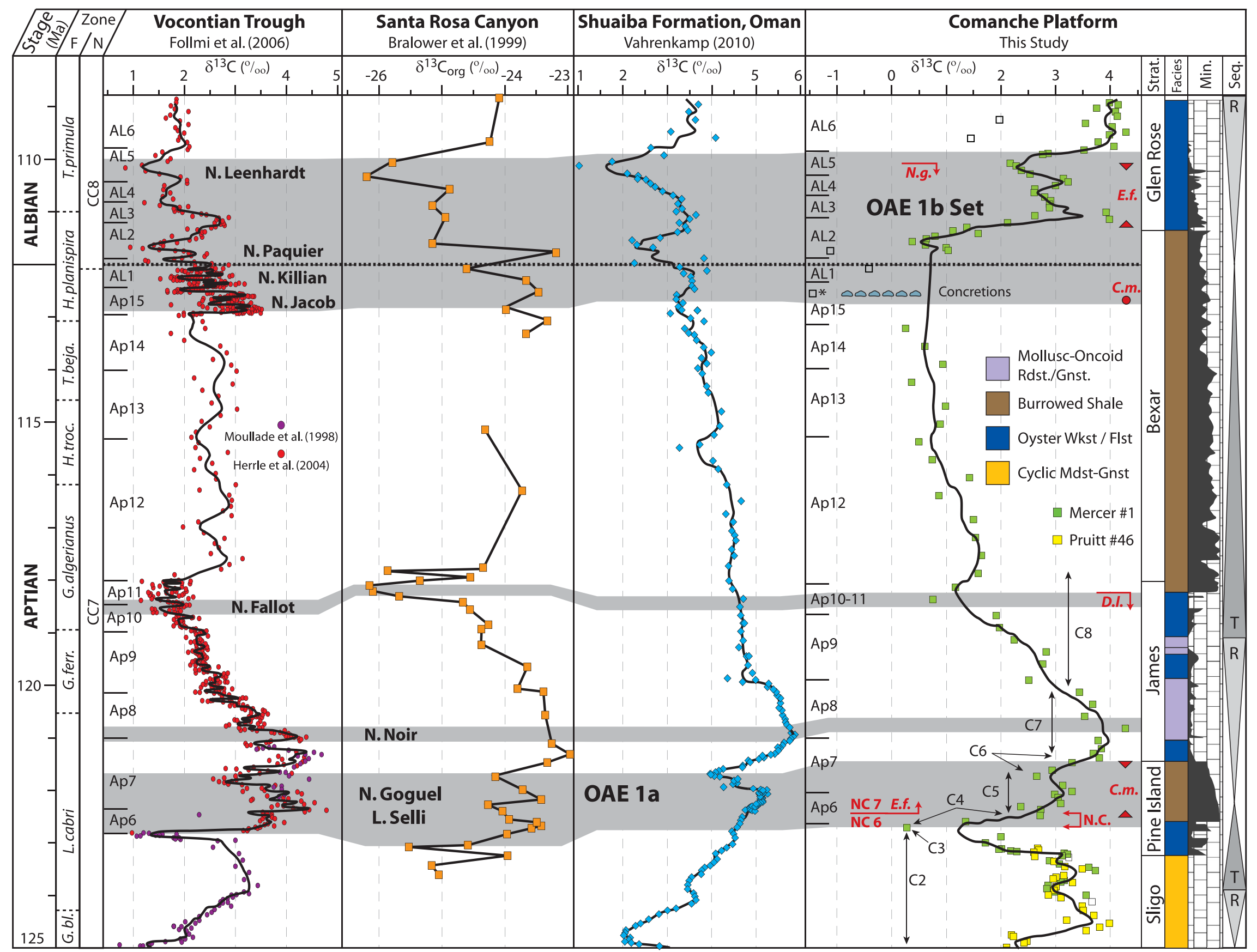

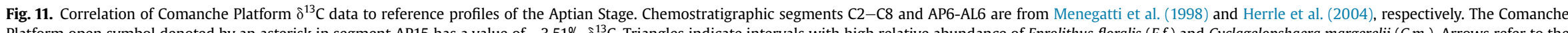

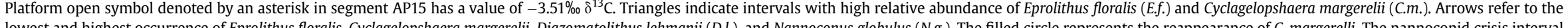

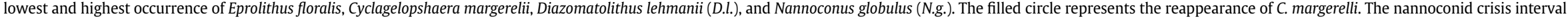
defined by Erba (1994) is denoted with arrows labeled N.C. Zones NC 6 and NC 7 are defined by.Roth (1978) 


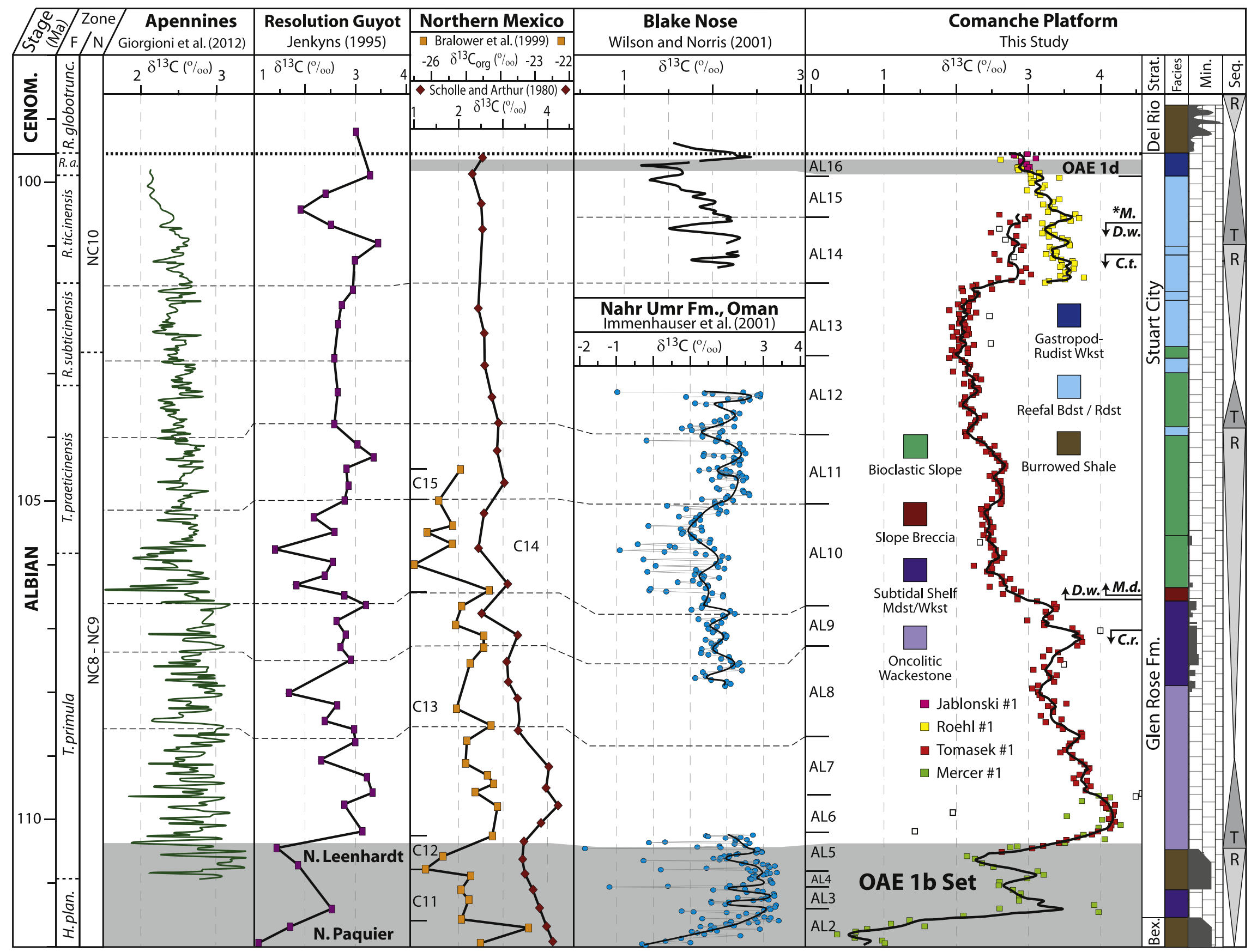

Fig. 12. Correlation of Comanche Platform $\delta^{13} \mathrm{C}$ data to reference profiles of the Albian Stage. Chemostratigraphic segments AL2-AL6 and C11-C15 are from Herrle et al. (2004) and Bralower et al. (1999), respectively. Segments AL7-AL19 are defined using Comanche Platform data. Arrows represent biostratigraphic highest or lowest occurrence for Colomiella recta (C.r.), Dictyoconus walnutensis (D.w.), Coskinolinoides texanus (C.t.) Microcalamoides diversus (M.d.) and Mexicaprina sp. $\left({ }^{*} \mathrm{M}\right)$. 
Apennines and not present in Resolution Guyot. In the Comanche Platform, the most positive excursion to $4.1 \%$ occurs above OAE $1 \mathrm{~b}$ (Figs. 11, 12), which is consistent with $\delta^{13}$ Ccarb data from Peregrina Canyon in Mexico, Resolution Guyot, and the Shuiaba Formation in Oman (Scholle and Arthur, 1980; Jenkyns, 1995; Vahrenkamp, 2010). Absolute $\delta^{13}$ Ccarb values among these locations are also similar. These data sets are distinct from the Vocontian Trough shifts and the $\delta^{13}$ Corg data from Santa Rosa Canyon in Mexico, which show the most positive excursions within OAE 1b (Bralower et al., 1999; Föllmi et al., 2006). These observations again suggest that regional oceanographic differences exerted an impact on the isotopic record of some areas.

Albian $\delta^{13} \mathrm{C}$ excursions are divided by chemostratigraphic segments C11-C15 (Bralower et al., 1999) and AL2-AL6 (Herrle et al., 2004). Albian segments AL7-AL16 are defined here using data from the Tomasek \#1 and Roehl \#1 cores (Figs. 7, 8). Following the methodology of Wissler et al. (2003), new segment boundaries are marked by $\delta^{13} \mathrm{C}$ profile turning points, changes in gradient, or excursion shape. Moreover, each segment is recognizable in multiple reference profiles.

After OAE $1 \mathrm{~b}$ and the positive shift to values of $4.1 \%{ }^{13} \mathrm{C}$ in AL6 of the early Albian, an oscillatory decrease to values of $3.5-3.6 \%$ in AL7 was followed by a concave-right decrease to $3.1 \% 0$ and increase to $3.4 \%$ in AL8. A pronounced peak, trough, and peak in segment AL9 corresponds to an influx of terrigenous clay in distal, subtidal shelf. The base of AL9 contains the youngest occurrence of the early Albian microfossil Colomiella recta (Scott, 1990). The base of AL10 contains the oldest occurrence of two middle Albian taxa, the foraminifera Dictyoconus walnutensis and the microfossil Microcalamoides diversus (Scott, 1990). The negative trend to $2.4 \%$ in $\mathrm{AL}$ 10 is followed by a concave-left trend to increasing to values of $2.6 \%$ and then decreasing to values of $2.1 \%$ in segment AL11. AL12 shows an oscillatory decrease to a minimum of $2.0 \%$, followed by a slow increase to $2.2 \%$ in AL13. A rapid increase to a range of 2.5-3.0\%o occurs at the base of AL14. Carbon isotope data from the Roehl \#1 core in AL14 are heavier than the Tomasek \#1 data by approximately $0.5 \%$, but follow a similar pattern. The top of AL14 is marked by the youngest occurrence (late Albian) of $D$. walnutensis in the Tomasek \#1core and the first occurrence of the late Albian rudist Mexicaprina sp. in the Roehl \#1 core. In AL15, the Roehl \#1 data decrease from 3.6\% to $3.0 \%$ in a manner that follows data from the western Atlantic at ODP site 1052 (Wilson and Norris, 2001). AL16 is defined by a further decrease to $2.8 \%$ and may be equivalent to OAE $1 \mathrm{~d}$. In south Texas, the signature of OAE $1 \mathrm{~d}$ is not present or poorly developed when compared to the high-resolution record documented by Wilson and Norris (2001) (Fig. 12).

\subsection{Cenomanian isotope profiles}

Speeton section $\delta^{13} \mathrm{C}$ data from England (Jarvis et al., 2006) provide a time-calibrated record of secular variability in the Cenomanian Stage (Fig. 13). High-resolution data from the Natih Formation of Oman (Vahrenkamp, 2013) and organic carbon data from the Atlantic coast of Morocco (Gertsch et al., 2010) serve as additional records. Correlation of lower Cenomanian events is complicated by low-amplitudes of the excursions $(<0.5 \% 0)$. Because Comanche Platform data from the Jablonski \#1 profile exhibit less scatter compared to the Roehl \#1 core, the moving average of the Jablonski \#1 data is used for correlation where available.

The negative shift in values associated with the AlbianCenomanian boundary event (Gale et al., 1996) coincides with the top of the Stuart City reef margin and the shift to shale deposition. The positive excursion in the reference profiles is not observed in south Texas, possibly due to a submarine hiatus at the contact between the Stuart City and Del Rio formations, or poor resolution of the data. Three positive excursions identified by Jarvis et al. (2006) as lower Cenomanian events $1-3$ are present in shelfal carbonates from Oman and in Planolites-burrowed shale of the Del Rio Formation. Calcareous nannofossil samples are barren in the Del Rio Formation, yet ammonites from the Del Rio and equivalent Grayson formations are early Cenomanian in age (Kennedy et al., 2005). Oscillatory trends in the globigerinid-bearing lower Buda Formation are inconsistent with the Engish Chalk and Natih Formation data, yet the three records provide a better fit surrounding the midDixoni event. Biostratigraphic analysis suggests an early to middle Cenomanian age of the Buda Formation (Scott et al., 2002).

Near the level of the mid-Cenomanian event, a prominent negative trend from $2.0 \%$ to $0.5 \%$ is present in the upper $4 \mathrm{~m}$ of the Buda Formation (Fig. 13). This trend may reflect a regional environmental perturbation that caused progressively more negative $\delta^{13} \mathrm{C}$ values and culminated in deposition of anoxic black shales in the overlying Eagle Ford. The negative $\delta^{13} \mathrm{C}$ trend in the upper Buda and lowermost Eagle Ford is broadly consistent with the Moroccan profile (Gertsch et al., 2010) and perhaps represents degrading environmental conditions on the Comanche Platform. All four profiles display a $1.0-1.5 \%$ positive excursion at the MidCenomanian Event.

The shift to $0.5 \%$ in the upper Buda is substantially more negative than any of the comparison data sets. This may reflect a diagenetic overprint derived from isotopically light pore fluids generated during sulfate reduction of organic matter in the overlying Eagle Ford shale (Irwin et al., 1977; Harbor, 2011). Sulfate diagenesis also possibly affected $\delta^{13} \mathrm{C}$ data in organic-rich shales of the Eagle Ford interval. The absolute $\delta^{13} \mathrm{C}$ values in south Texas are in the range of $0.5-1.8 \%$, which is significantly lower than the $2.0-3.0 \%$ range observed in the reference profiles. Oxygen isotope values also show a strong negative shift in the Eagle Ford interval of the Brechtel core and suggest some diagenetic overprint (Fig. 9).

Nevertheless, $\delta^{13} \mathrm{C}$ excursions in the Comanche Platform correspond to those of the reference sections and nannofossils demonstrate a middle to late Cenomanian age for most of the Eagle Ford Formation in this area. These black shales and mixed shale/calcareous siltstones represent maximum flooding of the 101-80 Ma Supersequence. A regional, intra-formational submarine unconformity at the youngest occurrence of Corollithion kennedyi removed the uppermost Cenomanian through Turonian interval. Hence, the record of OAE 2 is not recorded in Comanche Platform dataset.

\subsection{Turonian - Campanian isotope profiles}

The Turonian through Campanian section of the English Chalk $\delta^{13} \mathrm{C}$ curve (Jarvis et al., 2006) is well matched by high-resolution data from the southern neo-Tethys of Tibet (Wendler et al., 2009) and central Tethys of Italy (Stoll and Schrag, 2000). Although the upper Cenomanian to upper Turonian interval is unconformable in the Brechtel \#1 core, $4 \mathrm{ft}$ of uppermost Turonian, laminated to lightly-burrowed shale/calcareous siltstone is present above the unconformity (Fig. 14). More conformable outcrops outside the study area contain biostratigraphic and chemostratigraphic evidence of OAE 2 in the upper Eagle Ford Formation (Donovan et al., 2012). Thus the temporal extent of dysoxia/anoxia lasted from middle Cenomanian through Turonian on much of the platform. In the Brechtel \#1 profile, a concave-left trend toward more positive values during the Coniacian contains the White Fall Event. $\mathrm{A} \delta^{13} \mathrm{C}$ minimum at the Coniacian-Santonian boundary is followed by a positive $\delta^{13} \mathrm{C}$ trend in the Santonian to lower Campanian. Much of the Austin Chalk corresponds to OAE 3 and is comprised dominantly of cocoliths and bivalve fragments, yet it is low in total organic carbon. The oldest and youngest occurrence of Rhagodiscus 


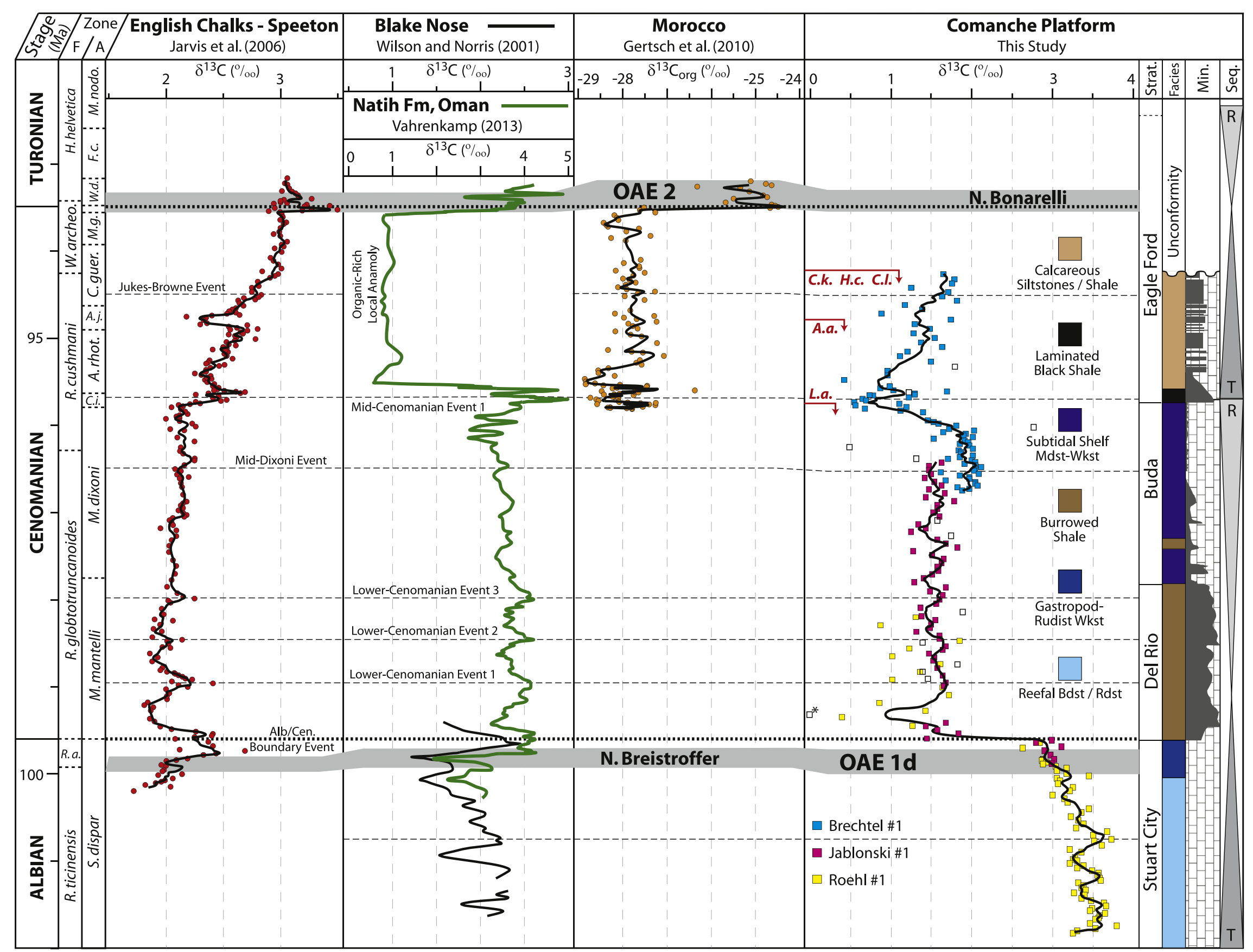

Fig. 13. Correlation of Comanche Platform $\delta^{13} \mathrm{C}$ data to reference profiles of the Cenomanian Stage. The symbol denoted by an asterisk has a value of $-0.64 \% \delta^{13} \mathrm{C}$. Calcareous nannofossils define the late Cenomanian age of the Eagle Ford in this core. Key occurrences are for Lithraphidites acutus (L.a.), Axopodorhabdus albanius (A.a.), Corollithion kennedyi (C.k.), Helenea chiastia (H.c.) and Cretarhabdus loriei (C.l.). 


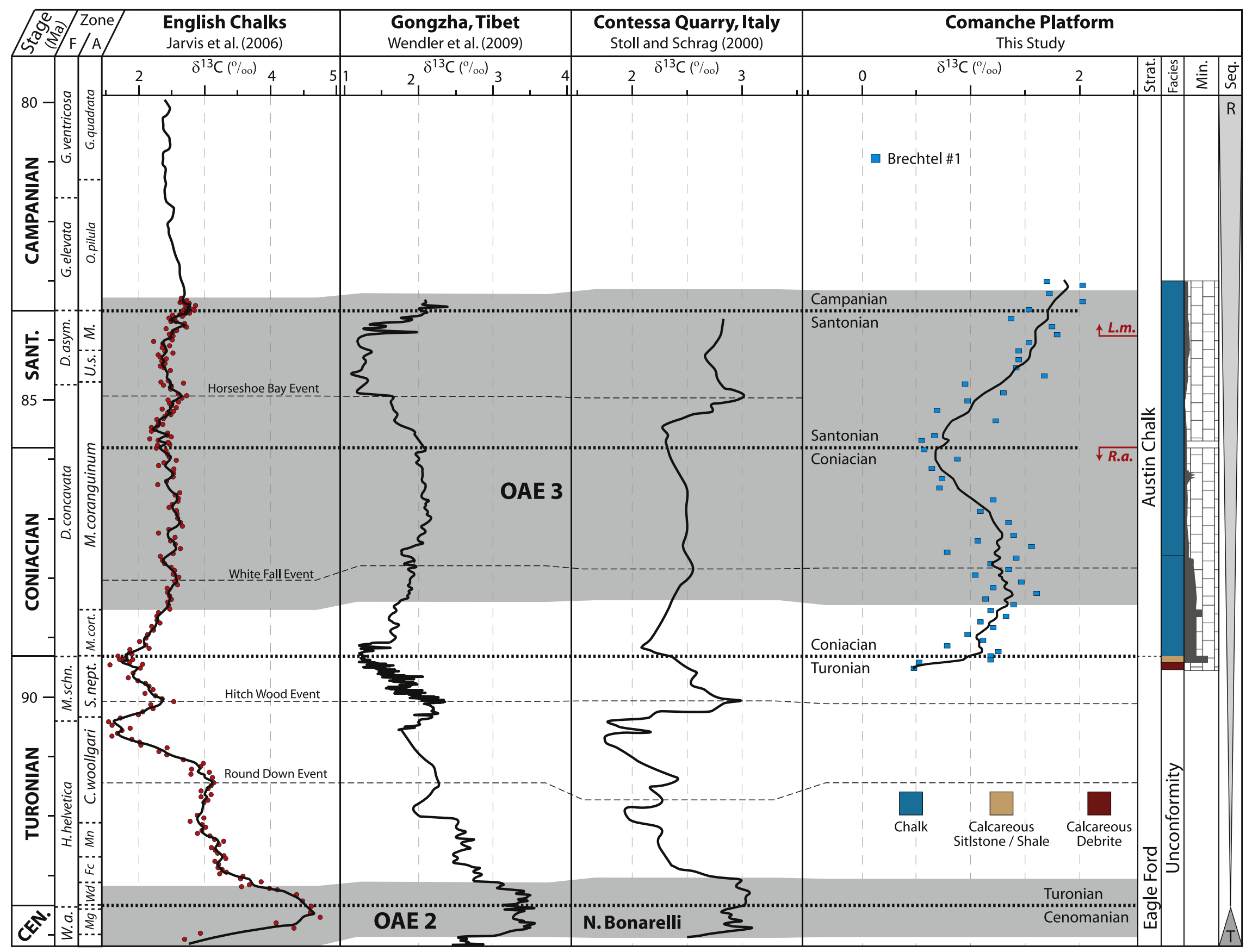




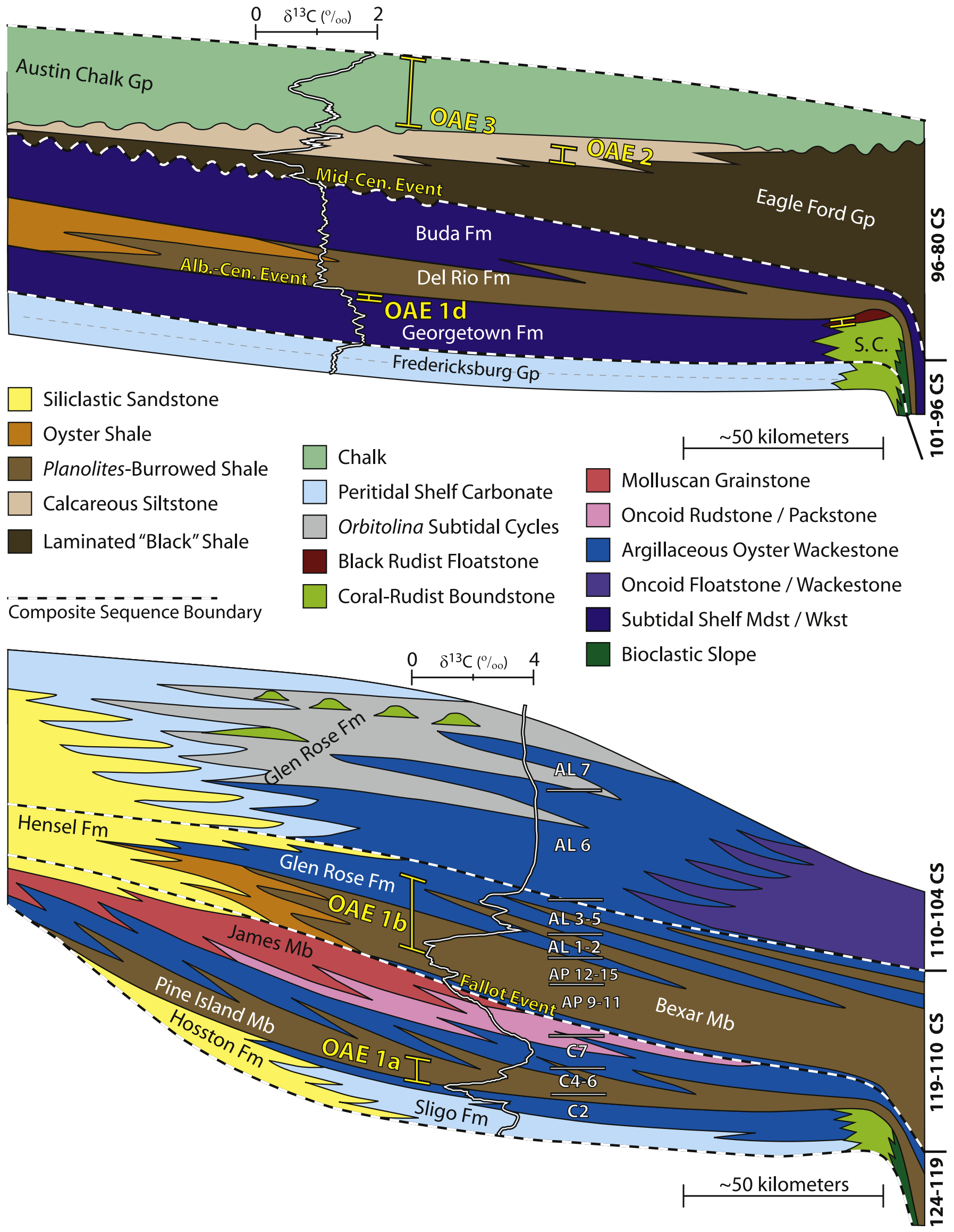

Fig. 15. Response of the Comanche Platform to OAEs, showing schematic depositional profiles and simplified lithofacies distributions prior to, during, and following each OAE. Not drawn to vertical scale. $\delta^{13} \mathrm{C}$ profiles are from the composite curve shown in Fig. 17. 
achlyostaurion and Lithastrinus moratus, respectively, provide some biotstratigraphic control.

\section{OAE control of Comanche platform drowning events}

On four separate occasions, low-amplitude eustatic sea-level rise and environmental stress surrounding oceanic anoxic events $1 \mathrm{a}, 1 \mathrm{~b}, 1 \mathrm{~d}$, and 2 caused termination of carbonate sediment deposition on the Comanche Platform. Two such periods caused the demise of aragonite-dominated, phototrophic carbonate systems with high-angle, rimmed shelf depositional profiles. Shale deposition accompanied or immediately followed each episode of platform drowning. Causal mechanisms of the OAEs and associated platform drowning events are generally a consequence of increased submarine volcanism in large igneous provinces (Sinton and Duncan, 1997; Larson and Erba, 1999; Weissert and Erba, 2004; Kuroda et al., 2007).

Notably, large igneous province volcanism caused displacement of ocean-water by submarine volcanic material, which was expressed by eustatic sea level rises. Volcanism also increased atmospheric $\mathrm{pCO}_{2}$ concentrations and caused greater ocean water acidity; processes that led to global warming, intensification of the hydrologic cycle, increased continental run-off and weathering, and biocalcification crises of calcareous organisms. Leaching of volcanic metals by submarine hydrothermal water was combined with greater transport of phosphorous from land to the marine realm. This nutrient delivery stimulated primary productivity in the world's oceans and ultimately led to locally anoxic conditions of varying severity (Erbacher et al., 1996; Bralower et al., 1999; Larson and Erba, 1999; Kump and Arthur, 1999; Weissert and Erba, 2004; Mort et al., 2007; Emeis and Weissert, 2009; Mehay et al., 2009; Tejada et al., 2009; Erba et al., 2010).

\subsection{Early Aptian drowning event}

Transgression during the early Aptian (124-119 Ma) composite sequence and the effects of OAE $1 \mathrm{a}$ drowned the shelf and reefmargin carbonates of the Sligo Formation (Figs. 2, 15). Submarine volcanism in the Ontong-Java Plateau (Larson, 1991; Larson and Erba, 1999; Tejada et al., 2002) coincided with an early Aptian eustatic rise that is observed in global stratigraphic records (Haq et al., 1988; Roehl and Ogg, 1996; Sahagian et al., 1996; Lehmann et al., 2000; Van Buchem et al., 2010; Phelps et al., 2014). Prior to OAE 1a, increasing clay mineral content in transgressive Sligo shelf carbonates of segment $\mathrm{C} 2$ is indicative of greater terrestrial weathering and/or decreased carbonate sedimentation rates (Figs. 5, 11). Undecompacted sediment accumulation rates at this time decreased by more than $60 \%$, from $2.6 \mathrm{~cm} / \mathrm{kyr}$ to $1.0 \mathrm{~cm} / \mathrm{kyr}$. The global nannoconid crisis suggestive of decreasing ocean-water $\mathrm{pH}$ during segments C3-C4 (Erba, 1994; Bralower et al., 1999; Larson and Erba, 1999; Erba et al., 2010) caps retrogradational patterns of calcitic, echinoid-oyster wackestones and argillaceous oyster biostromes on the shelf (Fig. 15). Increased terrigenous clay input, the rise in eustatic sea level, and the surge in ocean-water acidity increasingly stressed the carbonate factory, as evidenced by: (1) establishment of an oyster-dominated fauna, (2) decreasing Sligo shelf sediment accumulation rates, and (3) eventual drowning of the platform. These conditions arose prior to the Livello Selli event in OAE 1a and are paired with decreasing $\delta^{13} \mathrm{C}$ values consistent with increased output of depleted volcanogenic $\mathrm{CO}_{2}$ (Mehay et al., 2009). The specific event that triggered OAE 1a may be related to catastrophic methane hydrate release or simply a spike in atmospheric $p \mathrm{CO}_{2}$ (Jahren et al., 2001; Mehay et al., 2009; Vahrenkamp, 2010). Development of OAE 1a during segments C4-C6 in Pine Island shale occurred during maximum flooding of the Aptian (124-119 Ma) composite sequence and the broader Aptian-Albian Supersequence (Phelps et al., 2014). This burrowed shale unit contains ammonites and numerous plant fragments in landward cores located nearly $130 \mathrm{~km}$ from the Barremian shelf-edge (Fig. 4). Over the former shelf margin, Pine Island lithofacies transition to ammonite-rich, planarlaminated black shale indicative of dysoxic to anoxic conditions (Hull, 2011). Sediment accumulation rates in the middle-platform dropped to $0.55 \mathrm{~cm} / \mathrm{kyr}$, indicating that the dramatic increase in relative sea-level resulted from a moderate eustatic rise $(20-30 \mathrm{~m})$ that was greatly enhanced by diminished sedimentation rates and subsidence of the passive margin.

During and immediately following OAE 1a, carbonate sedimentation was largely restricted to shoreface systems of the Aptian (124-119 Ma) composite sequence (Fig. 15). Molluscan grainstone ramp clinoforms prograded from the Llano uplift and grade down depositional dip into oncoid rudstones to echinoid-oyster wackestones that distally interfinger with dysoxic, burrowed shale of the upper Pine Island Member (Loucks, 1976; Hull, 2011; Phelps et al., 2014). Because sediment accumulation rates remained low at $0.6 \mathrm{~cm} / \mathrm{kyr}$, progradation of carbonate clinoforms was not the result of increasing carbonate factory productivity, but rather a product of falling eustatic sea-level and diminished siliciclastic clay influx. Low sedimentation rates and a calcite-dominated, heterotrophic fauna dominated by oysters imply that the recovering carbonate factory continued to languish in stressed environmental conditions following OAE $1 \mathrm{a}$.

\subsection{Late Aptian drowning event}

The second drowning episode of the platform and the onset of burrowed-shale deposition began with the Fallot Event and continued through the Paquier event of the OAE 1b set. The Fallot Event and the OAE 1b set were preceded by long-term negative $\delta^{13} \mathrm{C}$ trends in segments Ap8-Ap9 and Ap12-Ap15, respectively (Fig. 11). Similar to OAE 1a, eustatic rise in the late Aptian (119-110 Ma) composite sequence and negative $\delta^{13} \mathrm{C}$ excursions were coincident with large igneous province volcanism in the Nauru-Mariana Basin and the Kerguelen Plateau (Duncan, 2002; Tejada et al., 2002; Weissert and Erba, 2004; Phelps et al., 2014).

Following the analogy to OAE 1a, platform drowning likely resulted from a combination of increasing ocean acidification (Weissert and Erba, 2004), increased terrigenous clay influx, and low amplitude eustatic sea level-rise $(\sim 10-20 \mathrm{~m})$. Shale deposition and deepening of relative sea-level were augmented by minimal sediment accumulation rates of $0.35 \mathrm{~cm} / \mathrm{kyr}$ and continued shelf subsidence. Planolites-burrowed Bexar shale of the middleplatform transitioned distally to planar-laminated shale above the former shelf-margin (Hull, 2011). While shale facies were deposited across most of the shelf, the shoreline consisted of glauconitic siliciclastic sandstone with carbonate caliche profiles in the Hensel Formation (Amsbury, 1996; Phelps et al., 2014). Oyster wackestone biostromes were transitional between shoreline siliciclastic sandstones and offshore shale (Fig. 15). Significantly, drowning of the platform and shale deposition in the Bexar Member commenced following the Fallot Event and largely preceded OAE $1 \mathrm{~b}$ by approximately 5 myr.

After the Paquier Event in $\mathrm{AL} 2$, carbonate sedimentation resumed as echinoid-oyster wackestones and oyster wackestones interfinger with distal shales during the temporal equivalent of the Leenhardt event and the remainder of OAE 1b (Figs. 2, 15). Following OAE 1b in transgression of the early Albian (110-104 Ma) composite sequence, shallow-marine packstone to grainstone cycles of the lower Glen Rose were confined to the inner-ramp, while the middle-ramp was dominated by environmentally stressed echinoid-oyster and Orbitolina assemblages (Fig. 15). In deeper 
areas of the platform, outer-ramp sedimentation was condensed into oncoid wackestones in segments AL5-AL6. The later widespread occurrence of aragonitic fauna in coral-rudist biostromes and patch reefs (Perkins, 1974; Loucks and Kerans, 2003; Scott et al., 2007) represented the return of normal marine conditions on the platform during segment AL 7.

\subsection{Albian-Cenomanian drowning event}

Continued phototrophic sedimentation in the middle to late Albian transformed the ramp profile into a rimmed-shelf with high-angle morphologies (Fig. 2). OAE 1d in the latest Albian is in the transgressive systems tract of the 101-96 Ma composite sequence and preceded the demise of the Stuart City reef margin. The change to black rudist floatstones and peloid-gastropod wackestones in the uppermost Albian portion of the reef margin suggests environmental stress surrounding OAE $1 \mathrm{~d}$ played a role in shelf-margin drowning (Figs. 8, 12). However, the AlbianCenomanian boundary event best matches the precise occurrence of platform drowning and may have played a greater role in demise of the prolific Albian carbonate factory. Although no late Albian volcanism in large igneous provinces is currently documented, several other carbonate platforms simultaneously drowned, possibly as a result of OAE $1 \mathrm{~d}$ or the Albian-Cenomanian boundary event (Groetsch et al., 1993). Maximum flooding of the 101-96 Ma composite sequence followed during deposition of Del Rio shale. Similar to sediments deposited surrounding OAEs $1 \mathrm{a}$ and $1 \mathrm{~b}$, fauna in the Del Rio Formation is dominated by oysters and agglutinated foraminifera (Fig. 15) (Lock et al., 2007). Incomplete recovery of the carbonate system occurred with deposition of subtidal shelf packstone/wackestone in the Buda Formation, which contains common oysters, gastropods, and coccoliths (Figs. 8, 15).

\subsection{Mid-Cenomanian drowning event}

The fourth drowning episode of the Comanche platform and deposition of Eagle Ford black shale transpired during transgression of the 96-80 Ma composite sequence and the lower frequency 101-80 Ma supersequence. Similar to OAEs 1a and 1b, OAE 2 is temporally linked to volcanism in large igneous provinces from the Caribbean, Madagascar and the Ontong-Java oceanic plateaus (Sinton and Duncan, 1997; Kuroda et al., 2007; Turgeon and Creaser, 2008; Elrick et al., 2009). However, as with OAE 1b, biostratigraphy and chemostratigraphy demonstrate that deposition of organicrich black shale in the Eagle Ford Group commenced approximately 2 myr prior to the global definition of OAE 2. Rather, organic-rich shale deposition on the Comanche Platform followed the mid-Cenomanian event and is not coupled with OAE 2. Similarly, the Natih Formation of Oman contains a locally anomalous, organic rich shale interval that followed the mid-Cenomanian event and substantially preceded OAE 2 (Fig. 13; Vahrenkamp, 2013). Late Cenomanian shale/calcareous siltstones in the Brechtel \#1 core of the middle-ramp changed facies distally into laminated black shale above the former shelf margin (Fig. 15). Faunas in these facies are calcitic and largely consist of planktic foraminifera, inoceramid bivalves, and coccoliths.

Following OAE 2 and continued deposition of Turonian anoxic/ dysoxic shale, Coniacian through lower Campanian chalk lithologies were deposited during OAE 3 (Jenkyns, 1980; Locklair et al., 2011). Although isolated shallow-water faunas are present in landward areas of the Campanian section (Swezey and Sullivan, 2004), faunal assemblages across the broader Comanche platform continued to consist primarily of coccoliths, oysters, and foraminifera. Thus the shallow-marine carbonate factory did not fully recover from the environmental stress that accompanied OAE 2 and persisted into OAE 3.

\section{Platform drowning and recovery surrounding oceanic anoxic events}

Synthesis of carbon isotope profiles, biostratigraphy, facies trends, and sequence stratigraphic interpretations reveals a pervasive environmental control on the Aptian-Albian and Cenomanian-Campanian Supersequences of the Comanche Platform. Four platform flooding events that terminated carbonate sedimentation during the supersequences are associated with OAEs. Composite sequences comprising the two main supersequences exhibit lithofacies proportions, platform geometries, and faunal compositions that result from the four environmentally controlled flooding events. Not only were the composite sequences containing an OAE affected, but the effects of environmental stress also propagated through subsequent composite sequences. A fourphase model describes the response of land-attached carbonate platforms to changing environmental conditions surrounding OAEs (Fig. 16). Results are specific to the Comanche Platform, but are generally applicable to additional land-attached platforms such as the northern Tethyan margin (Föllmi et al., 1994, 2006). Not all phases of the conceptual model are present surrounding each OAE, rather the idealized model is intended to capture a full cycle of platform drowning and stabilization. The model may be less applicable in areas where environmental crises did occur, but complete platform drowning did not transpire (D'Argenio et al., 2004: Wissler et al., 2004; Millan et al., 2009; Huck et al., 2010; Rameil et al., 2010).

The initial equilibrium phase (Fig. 16) assumes normal marine conditions and the presence of a high-angle, rimmed shelf with an aragonitic, coral- and rudist-dominated macrofauna. Additional phototrophic organisms, such as miliolid foraminifera and green algae, were present across the shelf. Examples include the Hauterivian-Barremian Sligo shelf and the middle to late Albian Stuart City margin. Values of $\delta^{13} \mathrm{C}$ profiles were confined in a narrow range and the relative proportion of terrigenous clay to carbonate accumulation was minimal. Eustacy was slowly increasing to stationary, yet high sediment acccumulation rates $(2.6-5.5 \mathrm{~cm} /$ kyr; Phelps et al., 2014) led to decreasing accommodation with aggradational to progradational shelf-margin trajectories and regressive shelf-interior facies patterns.

In the crisis phase, increasing volcanism in large igneous provinces led to greater atmospheric concentration of isotopically depleted $\mathrm{CO}_{2}$ (Kump and Arthur, 1999) that is reflected in decreasing $\delta^{13} \mathrm{C}$ values (Fig. 16). Ocean-water acidity increased in response to elevated $\mathrm{pCO}_{2}$ levels, and decreased saturation of ocean-water with respect to $\mathrm{CaCO}_{3}$ reduced the calcification ability of numerous aragonitic marine organisms such as coral, rudists, and green algae (Gattuso et al., 1998; Kleypas et al., 1999; Riebesell et al., 2000; Wissler et al., 2003). The link between increased $p \mathrm{CO}_{2}$ concentration and marine biocalcification rates is confirmed by documented nannoconid crises prior to the onset of oceanic anoxia and deposition of organic-rich shale (Erba, 1994; Bralower et al., 1999; Erba et al., 2010). During this crisis phase, $\delta^{13} \mathrm{C}$ profiles exhibit increasingly negative values and low-amplitude negative spikes suggestive of degenerative environmental events. At this time, the Comanche Platform exhibited transgressive facies patterns in the uppermost Sligo Formation shelf, uppermost James Member ramp, as well as the Georgetown Formation and uppermost Stuart City shelf margin (Fig. 15). These intervals preceded OAEs $1 \mathrm{a}, 1 \mathrm{~b}$, and $1 \mathrm{~d}$. They also form the transgressive systems tracts of the early Aptian (124-119 Ma), late Aptian (119-110 Ma), and Cenomanian (101-96 Ma) composite sequences. The Buda 


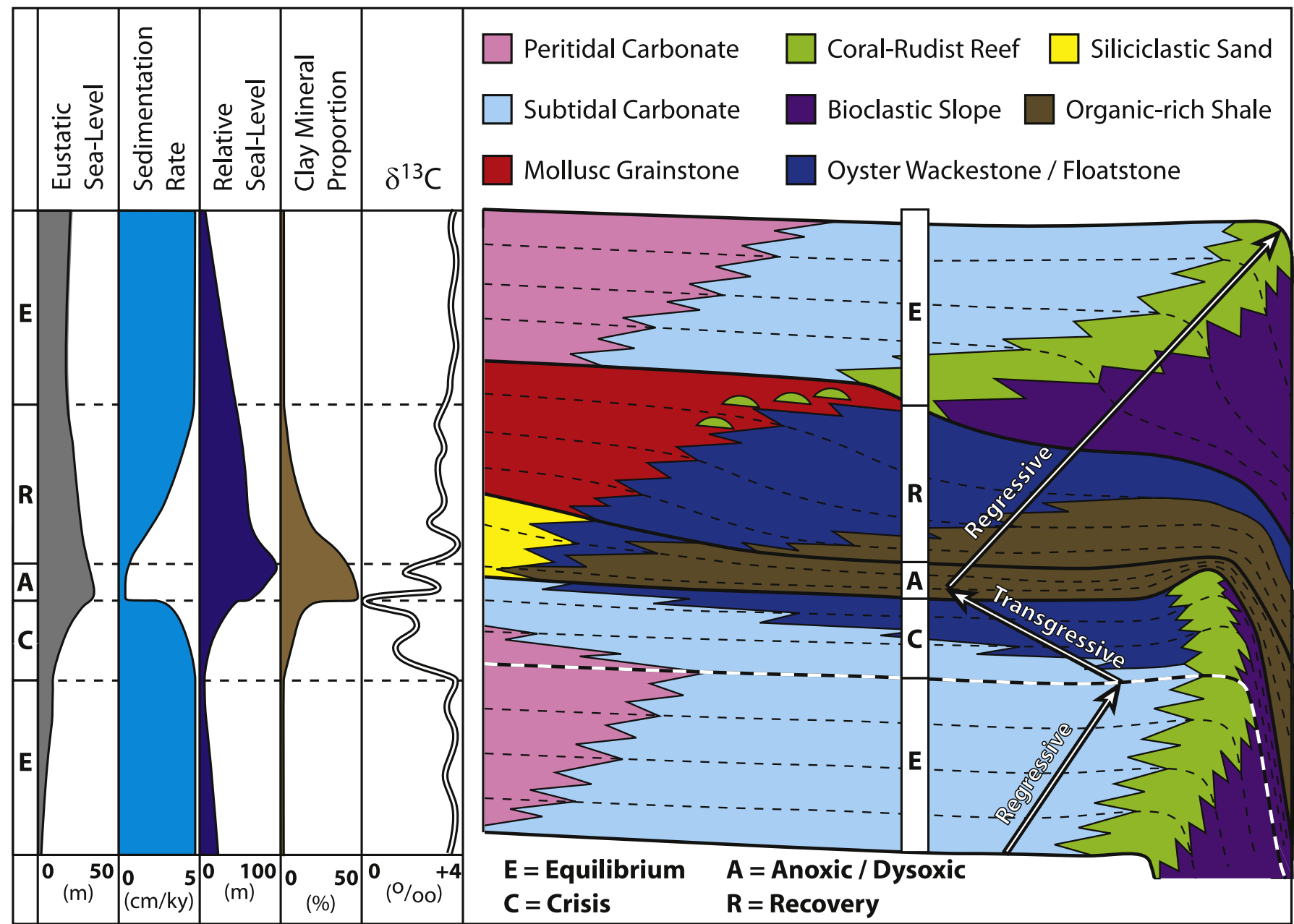

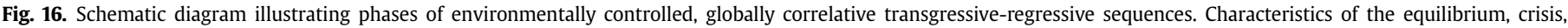

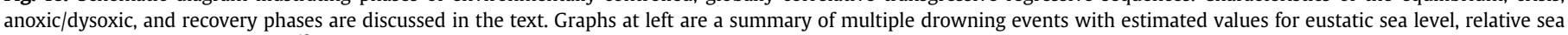
level and shale proportion. The $\delta^{13} \mathrm{C}$ curve is schematic.

Formation and lower Austin Chalk represent a more protracted state of environmental crisis on the platform and preceded OAEs 2 and 3. Relative sea-level rise during periods of crisis was less a result of rising eustacy and more a product of decreased carbonate sedimentation rates in response to increasing ocean-water acidity. Coral-rudist assemblages decreased in abundance or were absent, oyster biostromes transgressed across the shelf, and terrigenous clay began accumulating with increasing proportions. The final portion of this phase is marked by the most negative $\delta^{13} \mathrm{C}$ excursion and followed by strongly dysoxic to anoxic conditions.

Oceanic anoxic events, organic-rich shale deposition, and positive $\delta^{13} \mathrm{C}$ excursions characterize the anoxic phase (Fig. 16). Whether the immediate cause of anoxia was related to methane hydrate release (Jahren et al., 2001), a spike in volcanic activity and atmospheric $p \mathrm{CO}_{2}$ (Mehay et al., 2009), increased volcanic emission of trace metals into the water column (Larson and Erba, 1999), or simply greater pluviosity and nutrient input from fluvio-deltaic sources, the circumstances led to a peak in surface-water productivity, plummeting marine oxygen levels, and carbonate platform drowning. Of critical importance is the observation that dysoxic to anoxic conditions and complete drowning of the Comanche platform precisely coincided with the global definition of a major OAE only during the 1a event. Drowning of the Comanche Platform and commencement of shale deposition preceded OAEs $1 \mathrm{~b}$ and 2 . The link to OAE $1 \mathrm{~d}$ is not well constrained but the event likely occurred prior to platform drowning.

Recent work suggests that atmospheric $p \mathrm{CO}_{2}$ levels derived from volcanic sources intensified prior to OAEs over time intervals spanning several tens of kiloyears (Mehay et al., 2009; Keller et al., 2011). Vahrenkamp (2010) postulated that the increased input of isotopically light carbon from volcanic sources lasted a few million years and is manifest by multiple negative $\delta^{13} \mathrm{C}$ excursions surrounding OAE 1a in Oman. Similar negative excursions prior to OAE 1a are observed in the Comanche Platform data (Figs. 10, 11, 16). The global conditions favoring anoxic events persisted over extensive time spans surrounding the major OAEs. However, local environmental conditions of a region dictated the exact timing of anoxia, carbonate platform drowning, and deposition of the subsequent organic-rich shale intervals. With the exception of OAE $1 \mathrm{a}$, younger drowning episodes on the Comanche Platform occurred adjacent to OAEs $1 \mathrm{~b}, 1 \mathrm{~d}$, and 2 during a broader set of global circumstances conducive to anoxia, but these OAEs were not directly coincident with initial platform drowning. Rather, three of four episodes of platform drowning correspond more closely to ancillary events surrounding the main OAEs. Platform drowning prior to OAE $1 \mathrm{~b}$ is better aligned temporally with the Fallot event. Drowning following OAE 1d may have more precisely corresponded to the Albian-Cenomanian boundary event. Complete drowning of the 
platform and diminished carbonate productivity prior to OAE 2 matches best with the Mid-Cenomanian event. The specific anoxic "sub-event" (for example: Fallot event, Albian-Cenomanian boundary event, Mid-Cenomanian event) that was most detrimental to a given carbonate system differed globally based on regional paleoceanographic conditions and must not necessarily correspond to a classically defined OAE. Rather the major OAEs (1a, $1 \mathrm{~b}, 1 \mathrm{~d}, 2)$ represent broader periods of time in which global paleoceanographic conditions were conducive to anoxia and several anoxic sub-events occurred, any one of which may have been most important for a specific carbonate province.

During the anoxic phase, eustatic sea level may have reached $10-50 \mathrm{~m}$ above levels of the equilibrium phase, but relative sealevel rise of $50-100 \mathrm{~m}$ and maximum flooding of the platform was enhanced by low sediment accumulation rates $(0.3-0.5 \mathrm{~cm} /$ kyr) and platform subsidence. Shale deposition was partially a function of background sedimentation with high rates of organiccarbon burial and also a result of increased clay input from continental weathering. Radiolaria and benthic foraminifera assemblages underwent rapid extinction and radiation episodes in response to fluctuating nutrient levels (Erbacher et al., 1996; Parente et al., 2008). Shoreline sedimentation in low-angle ramp clinoforms consisted of reworked molluscan-oyster debris or glauconitic siliciclastic sandstones, particularly surrounding OAEs 1a and 1b of the early Aptian (124-119 Ma) and late Aptian (119-110 Ma) composite sequences. Similar facies trends are observed in northern Tethyan margins (Föllmi et al., 1994, 2006).

Following oceanic anoxia, the recovery phase of the platform is characterized by stabilizing $\delta^{13} \mathrm{C}$ profiles with minor excursions (Fig. 16). The carbonate factory re-established in bathymetrically shallow areas near the shoreline as ocean-water acidity decreased and sedimentation rates slowly increased. Isolated carbonate platforms, such as those in the Pacific Ocean (Groetsch et al., 1993; Jenkyns, 1995), may not have begun the recovery phase, precisely because they lacked shallow shorelines from which to establish active sedimentation. Recovery fauna deposited in dysoxic conditions amidst decreasing shale accumulation consisted of calcitedominated assemblages with oysters and fewer echinoderms following OAEs $1 \mathrm{a}, 1 \mathrm{~b}$, and $1 \mathrm{~d}$. Following OAE 2, recovery assemblages in the Austin Chalk contained abundant coccolithophorids, common inoceramid bivalves, and fewer oysters. Eustatic sea levels were slowly falling to stationary in composite sequence highstands and caused progradation of ramp clinoforms with regressive platform geometries. Coral-rudist assemblages were generally absent, but were slowly introduced in bioherms and solitary platformmargin reefs as normal marine conditions returned. Equilibrium conditions re-established regressive shelf-margin reefs following the Aptian OAEs. However in other circumstances the carbonate shelf never fully recovered to equilibrium conditions, as was the case of the Comanche Platform following OAEs 2 and 3.

\section{Conclusions}

Compilation of the eight $\delta^{13} \mathrm{C}$ profiles from the Comanche Platform allows construction of a continuous secular carbon isotope curve spanning approximately 52 myr that is derived from lower Hauterivian through lower Campanian strata exceeding $1000 \mathrm{~m}$ in thickness (Fig. 17). Correlation of Hauterivian and Barremian data from the Comanche Platform to global reference profiles indicates that isotope investigations outside of the northern Tethys may provide further insight into global carbon cycling prior to OAE 1a. Aptian data are consistent across the various reference profiles and provide supplemental information regarding the global impact of OAEs $1 \mathrm{a}$ and $1 \mathrm{~b}$ across the spectrum of carbonate environments. Comanche Platform data for the Albian Stage are a high-resolution data set that allows refined definition of globally correlative chemostratigraphic segments. Lower Cenomanian global correlations are equivocal because excursions are of low amplitude. However, the Mid-Cenomanian event shows significant excursions and coincides with shale deposition and organic matter burial on the Comanche Platform. The uppermost Cenomanian through upper Turonian section is not present in this data set, but correlation of uppermost Turonian through lower Campanian data to global reference sections is readily accomplished.

Prior to global oceanic anoxic events, long-term transgressions and negative trends in $\delta^{13} \mathrm{C}$ profiles are consistent with increased rates of submarine volcanism in large-igneous provinces as the primary driver of environmental stress surrounding OAEs 1a, 1b, 1d and 2 . If considered the only external forcing mechanism, eustatic sea-level rises of $10-60 \mathrm{~m} / \mathrm{myr}$ were probably insufficient to cause drowning of the Comanche Platform because reef-margin sediment accumulation rates reached $71 \mathrm{~m} / \mathrm{myr}$ in the Stuart City reefmargin (Hancock and Kauffman, 1979; Haq et al., 1988; Sahagian et al., 1996; Miller et al., 2004). Additional forcing mechanisms must have been involved to cause repeated drowning of otherwise healthy carbonate factories in the Sligo and Stuart City depositional systems. Environmental perturbations surrounding the OAEs, especially increased surface water acidity and influx of siliciclastics from intensified continental weathering (Weissert and Erba, 2004; Emeis and Weissert, 2009; Erba et al., 2010), caused carbonate sediment production to substantially diminish surrounding the anoxic events. Thus, volcanism in large igneous provinces led to a combination of eustatic sea level rise and environmental stress that repeatedly caused carbonate sedimentation to terminate on the Comanche Platform. However, the precise timing of each platform drowning event and start of organic-rich shale deposition was a function of local oceanographic conditions that did not always correspond with the biostratigraphic and chemostratigraphic definitions of the major OAEs. Complete platform drowning in the early Aptian coincided with the biostratigraphic and chemostratigraphic definition of OAE 1a. However, the start of platform drowning episodes containing OAEs $1 \mathrm{~b}, 1 \mathrm{~d}$, and 2 more precisely correspond to the timing of anoxic sub-events, including the Fallot, Albian-Cenomanian boundary, and Mid-Cenomanian events.

The south Texas composite $\delta^{13} \mathrm{C}$ profile and stratigraphic analysis document the impact of OAEs $1 \mathrm{a}, 1 \mathrm{~b}, 1 \mathrm{~d}, 2$ and 3 on the morphologic development of the Comanche Platform. Four carbonate platform drowning episodes caused development of two transgressive-regressive supersequences (Aptian-Albian and Cenomanian-Campanian) characterized by equilibrium, crisis, anoxic, and recovery phases. Stratigraphic packages of greatest thickness and highest sediment accumulation rates averaging $4 \mathrm{~cm} /$ kyr occur in the equilibrium phases. Equilibirum phases contain aragonitic, coral-rudist phototrophic faunal assemblages and are represented by carbonate-dominated shelves of the HauterivianBarremian and Albian intervals (Figs. 2, 15, 16). Crisis phases are associated with transgressive facies trends, calcite-dominated heterotrophic fauna, diminishing sedimentation rates, and increasing shale accumulations. Anoxic phases contain the thinnest stratigraphic packages with the lowest sediment accumulation rates averaging $0.3-0.5 \mathrm{~cm} / \mathrm{kyr}$. Associated shale intervals deposited during or surrounding the OAEs represent maximum flooding zones of composite sequences. Pine Island Member, Bexar Member, Del Rio Formation, and Eagle Ford Group shale units in south Texas are associated with OAEs, but the shale units do not always exactly coincide with the global biostratigraphic and chemostratigraphic definitions of the events. These units represent only $8 \%$ of the total section thickness but encompass approximately $39 \%$ of the time through which platform sediments were deposited. Following each OAE and shale deposition, recovery phases re-initiated the 
Comanche Platform - Composite Thickness Profile Comanche Platform - Composite Time Profile

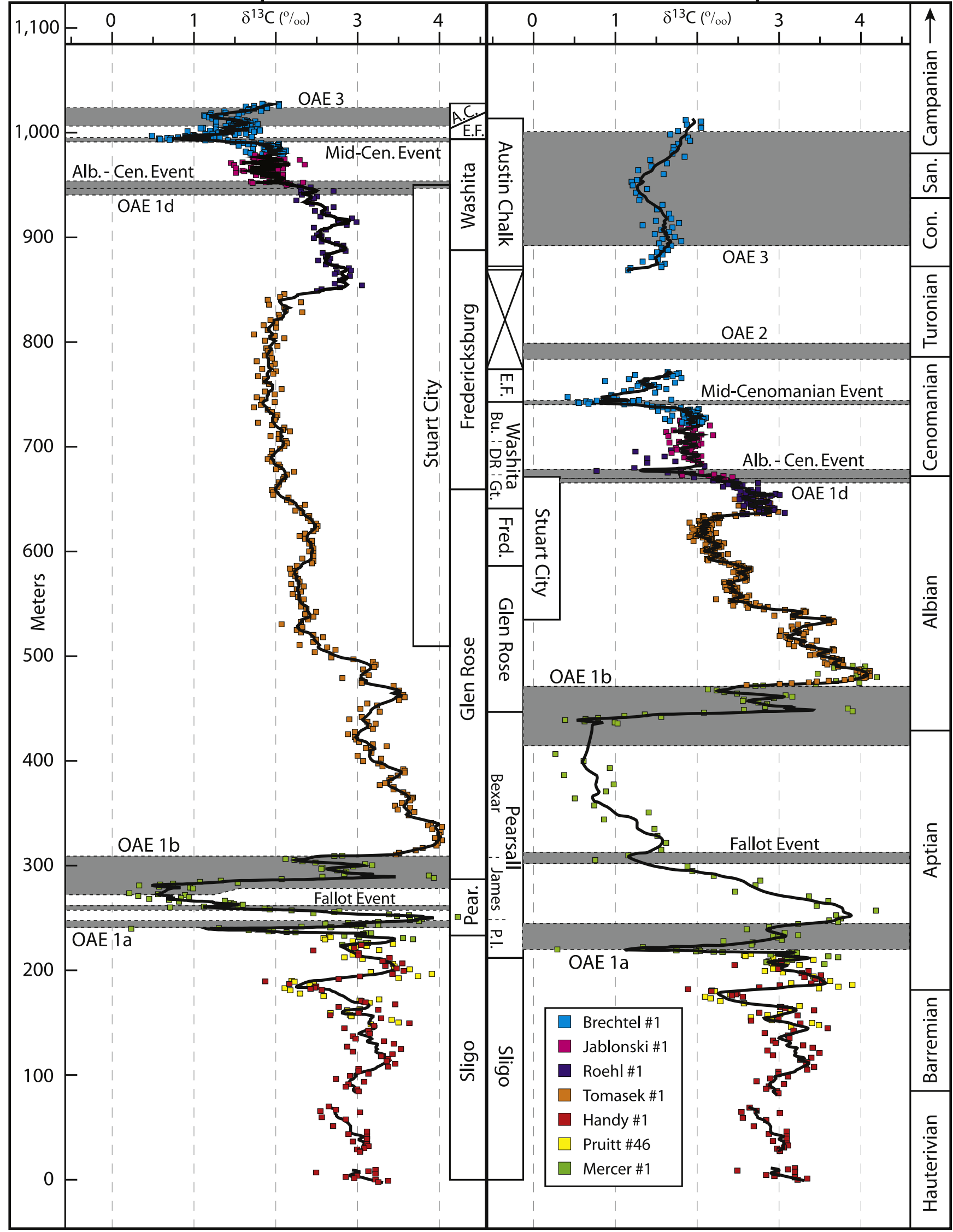

Fig. 17. Composite carbon isotope curves for the Comanche Platform. At left the data are plotted against cumulative thickness of the stratigraphic section. At right the data are plotted against time. 
carbonate factory at the shoreline via regressive ramp depositional systems containing calcitic, oyster- or coccolithophorid-dominated faunas. Equilibrium conditions were again attained following OAEs $1 \mathrm{a}$ and $1 \mathrm{~b}$ in the Aptian-Albian supersequence, but were not fully re-established following OAEs $1 \mathrm{~d}, 2$ and 3 in the CenomanianCampanian supersequence.

\section{Acknowledgments}

The authors thank ConocoPhillips for stable isotope analytical funding. Funding was also contributed by, BHP-Billiton, AAPG Grants-in-Aid, industrial associates of the Reservoir Characterization Research Laboratory, the Bureau of Economic Geology, and the Jackson School of Geosciences at the University of Texas at Austin. Early reviews and technical comments were provided by R. Scott, X. Janson, T. Quinn and W. Fisher.

\section{References}

Allan, J.R., Matthews, R.K., 1982. Isotope signatures associated with early meteoric diagenesis. Sedimentology 29, 797-817.

Amodio, S., Ferreri, V., D'Argenio, B., Weissert, H., Sprovieri, M., 2008. Carbonisotope stratigraphy and cyclostratigraphy of shallow-marine carbonates; the case of San Lorenzello, Lower Cretaceous of southern Italy. Cretaceous Research 29, 803-813.

Amsbury, D.L., 1996. Pearsall (Aptian Cretaceous) subsurface to outcrop sequence stratigraphy, central Texas. Transactions of the Gulf Coast Association of Geological Societies 46, 1-7.

Arthur, M.A., Jenkyns, H.C., Brumsack, H.J., Schlanger, S.O., 1990. Stratigraphy, geochemistry, and paleoceanography of organic carbon-rich Cretaceous sequences. In: Ginsburg, R.N., Beaudoin, B. (Eds.), Cretaceous resources, events and rhythms. Kluwer Academic Publishers, Dordrecht, pp. 75-119.

Arthur, M.A., Sageman, B.B., 1994. Marine black shales; depositional mechanisms and environments of ancient deposits. Annual Review of Earth and Planetary Sciences 22, 499-551.

Arthur, M.A., Schlanger, S.O., 1979. Cretaceous 'oceanic anoxic events' as causal factors in development of reef-reservoired giant oil fields. American Association of Petroleum Geologists Bulletin 63, 870-885.

Bebout, D.G., 1977. Sligo and Hosston depositional patterns, subsurface of South Texas. In: Bebout, D.G., Loucks, R.G. (Eds.), Cretaceous carbonates of Texas and Mexico: applications to subsurface exploration. Texas Bureau of Economic Geology Report of Investigations 89, pp. 79-96.

Bralower, T.J., 1988. Calcareous nannofossil biostratigraphy and assemblages of the Cenomanian-Turonian boundary interval: implications for the origin and timing of oceanic anoxia. Paleoceanography 3, 275-316.

Bralower, T.J., CoBabe, E., Clement, B., Sliter, W.V., Osburn, C.L., Longoria, J., 1999. The record of global change in Mid-Cretaceous (Barremian-Albian) sections from the Sierra Madre, northeastern Mexico. Journal of Foraminiferal Research 29, 418-437.

Buffler, R., Watkins, J.S., Schaub, F.J., Worzel, J.L., 1980. Structure and early geologic history of the deep central Gulf of Mexico Basin. Proceedings of the Symposium on the Origin of the Gulf of Mexico and the Early Opening of the Central Atlantic. Louisiana State University, Baton Rouge, pp. 3-16.

Coogan, A.H., 1977. Early and Middle Cretaceous Hippuritacea (rudists) of the Gulf Coast. In: Bebout, D.G., Loucks, R.G. (Eds.), Cretaceous carbonates of Texas and Mexico: applications to subsurface exploration. Texas Bureau of Economic Geology Report of Investigations 89, pp. 32-70.

D'Argenio, B., Ferreri, V., Weissert, H., Amodio, S., Buonocunto, F.P., Wissler, L., 2004. A multidisciplinary approach to global correlation and geochronology. The Cretaceous shallow-water carbonates of southern Apennines, Italy. In: D'Argenio, B., Fischer, A.G., Silva, I.P., Weissert, H., Ferreri, V. (Eds.), Cyclostratigraphy: approaches and case histories. Society for Sedimentary Geology, Tulsa, pp. 103-122.

Dawson, W.C., 1997. Limestone microfacies and sequence stratigraphy: Eagle Ford Group (Cenomanian-Turonian) north-central Texas outcrops. Transactions of the Gulf Coast Association of Geological Societies 47, 99-106.

Dickson, J.A.D., Coleman, M.L., 1980. Changes in carbon and oxygen isotope composition during limestone diagenesis. Sedimentology 27, 107-118.

Donovan, A.D., Staerker, T.S., Pramudito, A., Li, W., Corbett, M.J., Lowery, C.M., Romero, A.M., Gardner, R.D., 2012. The Eagle Ford outcrops of west Texas: a laboratory for understanding heterogeneities within unconventional mudstone reservoirs. GCAGS Journal 1, 162-185.

Dravis, J.J., 1980. Sedimentology and diagenesis of the Upper Cretaceous Austin Chalk Formation, South Texas and northern Mexico. Unpubl. PhD Dissertation. Rice University, Houston, Texas, 513 pp.

Duncan, R.A., 2002. A time frame for construction of the Kerguelen Plateau and Broken Ridge. Journal of Petrology 43, 1109-1119.

Emeis, K.-C., Weissert, H., 2009. Tethyan-Mediterranean organic carbon-rich sediments from Mesozoic black shales to sapropels. Sedimentology 56, 247-266.
Elrick, M., Molina-Garza, R., Duncan, R., Snow, L., 2009. C-Isotope stratigraphy and paleoenvironmental changes across OAE2 (mid-Cretaceous) from shallowwater platform carbonates of southern Mexico. Earth and Planetary Science Letters 277, 295-306.

Erba, E., 1994. Nannofossils and superplumes: the Early Aptian "nannoconid crisis" Paleoceanography 9, 483-501.

Erba, E., Bottini, C., Weissert, H.J., Keller, C.E., 2010. Calcareous nannoplankton response to surface-water acidification around Oceanic Anoxic Event 1a. Science 329, 428-432.

Erba, E., Channell, J.E.T., Claps, M., Jones, C., Larson, R., Opdyke, B., Premoli Silva, I., Riva, A., Salvini, G., Torricelli, S., 1999. Integrated stratigraphy of the Cismon Apticore (southern Alps, Italy); a "reference section" for the Barremian-Aptian interval at low latitudes. Journal of Foraminiferal Research 29, 371-391.

Erbacher, J., Thurow, J., 1997. Influence of oceanic anoxic events on the evolution of Mid-Cretaceous Radiolaria in the North Atlantic and western Tethys. Marine Micropaleontology 30, 139-158.

Erbacher, J., Thurow, J., Littke, R., 1996. Evolution patterns of Radiolaria and organic matter variations: a new approach to identify sea-level changes in midCretaceous pelagic environments. Geology 24, 499-502.

Erbacher, J., Friedrich, O., Wilson, P.A., Lehmann, J., Weiss, W., 2011. Short-term warming events during the boreal Albian (mid-Cretaceous). Geology 39, 223-226.

Ewing, T.E., 2010. Pre-Pearsall Geology and Exploration Plays in South Texas. Transactions of the Gulf Coast Association of Geological Societies 60, 241-260.

Faust, M.J., 1990. Seismic stratigraphy of the mid-Cretaceous unconformity (MCU) in the central Gulf of Mexico basin. Geophysics 55, 868-884.

Föllmi, K.B., Godet, A., Bodin, S., Linder, P., 2006. Interactions between environmental change and shallow water carbonate buildup along the northern Tethyan margin and their impact on the Early Cretaceous carbon isotope record. Paleoceanography 21, 1-16.

Föllmi, K.B., Weissert, H., Bisping, M., Funk, H., 1994. Phosphogenesis, carbonisotope stratigraphy, and carbonate-platform evolution along the Lower Cretaceous northern Tethyan margin. Geological Society of America Bulletin 106, 729-746.

Friedrich, O., Reichelt, K., Herrle, J.O., Lehmann, J., Pross, J., Hemleben, C., 2003 Formation of the late Aptian Niveau Fallot black shales in the Vocontian Basin (SE France); evidence from Foraminifera, palynomorphs, and stable isotopes. Marine Micropaleontology 49, 65-85.

Gale, A.S., Kennedy, W.J., Burnett, J.A., Caron, M., Kidd, B.E., 1996. The Late Albian to Early Cenomanian succession at Mont Risou near Rosans (Drome, SE France): an integrated study (ammonites, inoceramids, planktonic foraminifera, nannofossils, oxygen and carbon isotopes). Cretaceous Research 17, 515-606.

Gattuso, J.P., Frankignoulle, M., Bourge, I., Romaine, S., Buddemeier, R.W., 1998. Effect of calcium carbonate saturation of seawater on coral calcification. Global and Planetary Change 18, 37-46.

Gertsch, B., Adatte, T., Keller, G., Tantawy, A.A.A.M., Berner, Z., Mort, H.P. Fleitmann, D., 2010. Middle and late Cenomanian oceanic anoxic events in shallow and deeper shelf environments of western Morocco. Sedimentology 57, 1430-1462.

Giorgioni, M., Weissert, J., Bernasconi, S.M., Hochuli, P.A, Coccioni, R., Keller, C.E. 2012. Orbital control on carbon cycle and oceanography in the mid-Cretaceous greenhouse. Paleoceanography 27, PA1204.

Godet, A., Bodin, S., Foellmi, K.B., Vermeulen, J., Gardin, S., Fiet, N., Adatte, T. Berner, Z., Stueben, D., Van de Schootbrugge, B., 2006. Evolution of the marine stable carbon-isotope record during the Early Cretaceous; a focus on the late Hauterivian and Barremian in the Tethyan realm. Earth and Planetary Science Letters 242, 254-271.

Grabowski Jr., G.J., 1995. Organic-rich chalks and calcareous mudstones of the Upper Cretaceous Austin Chalk and Eagle Ford formation, south-central Texas, USA. In: Katz, B. (Ed.), Petroleum source rocks. Springer Verlag, New York, pp. 209-234.

Groetsch, J., Schroeder, R., Noe, S., Fluegel, E., 1993. Carbonate platforms as recorders of high-amplitude eustatic sea-level fluctuations; the late Albian appenninicaevent. Basin Research 5, 197-212.

Groetsch, J. Billing I, Vahrenkamp, V 1998. Carbon-isotope stratigraphy in shallow-water carbonates; implications for Cretaceous black-shale deposition. Sedimentology 45, 623-634.

Hancock, J.M., Kauffman, E.G., 1979. The great transgressions of the Late Cretaceous. Journal of the Geological Society 136, 175-186.

Handoh, I.C., Lenton, T.M., 2003. Periodic mid-Cretaceous oceanic anoxic events linked by oscillations of the phosphorous and oxygen biogeochemical cycles. Global Biogeochemical Cycles 17, 1-11.

Harbor, R.L., 2011. Facies characterization and stratigraphic architecture of organicrich mudrocks, upper Cretaceous Eagle Ford Fm, south Texas. Unpubl. M.Sc thesis. University of Texas at Austin, Austin, Texas, 184 pp.

Haq, B.U., Hardenbol, J., Vail, P.R., 1988. Mesozoic and Cenozoic chronostratigraphy and cycles of sea-level change. In: Wilgus, C.K., Hastings, B.S., Kendall, C.G.S.C. Posamentier, H.W., Ross, C.A., Van Wagoner, J.C. (Eds.), Sea-level changes: an integrated approach. Special Publication, pp. 72-108. Society of Economic Paleontologists and Mineralogists 42.

Herrle, J.O., Koessler, P., Friedrich, O., Erlenkeuser, H., Hemleben, C., 2004. Highresolution carbon isotope records of the Aptian to lower Albian from SE France and the Mazagan Plateau (DSDP Site 545); a stratigraphic tool for paleoceanographic and paleobiologic reconstruction. Earth and Planetary Science Letters 218, 149-161. 
Huck, S., Rameil, N., Korbar, T., Heimhofer, U., Wieczorek, T.D., Immenhauser, A., 2010. Latitudinally different responses of Tethyan shoal-water carbonate systems to the Early Aptian oceanic anoxic event (OAE 1a). Sedimentology 57, 1585-1614.

Hull, D.C., 2011. Stratigraphic architecture, depositional systems, and reservoir characteristics of the Pearsall shale-gas system, lower Cretaceous, south Texas. Unpubl. M.Sc. thesis. The University of Texas at Austin, Austin, Texas, 192 pp.

Immenhauser, A., Scott, R.W., 2002. An estimate of Albian sea-level amplitudes and its implication for the duration of stratigraphic hiatuses. Sedimentary Geology $152,19-28$.

Immenhauser, A., Della Porta, G., Kenter, J.A.M., Bahamonde, J.R., 2003. An alternative model for positive shifts in shallow-marine carbonate $\delta^{13} \mathrm{C}$ and $\delta^{18} \mathrm{O}$. Sedimentology 50, 953-959.

Immenhauser, A., van der Kooij, B., van Vliet, A., Schlager, W., Scott, R.W., 2001. An ocean-facing Aptian-Albian carbonate margin, Oman. Sedimentology 48, 1187-1207.

Immenhauser, A., Hillgaertner, H., van Bentum, E., 2005. Microbial-foraminifera episodes in the early Aptian of the southern Tethyan margin; ecological significance and possible relation to oceanic anoxic event 1 a. Sedimentology 52, 77-99.

Irwin, H., Curtis, C., Coleman, M., 1977. Isotopic evidence for source of diagenetic carbonates formed during burial of organic-rich sediments. Nature (London) 269, 209-213.

Jahren, A.H., Arens, N.C., Sarmiento, G., Guerrero, J., Amundston, R., 2001. Terrestrial record of methane hydrate dissociation in the Early Cretaceous. Geology 29, $159-162$.

Jarvis, I., Mabrouk, A., Moody, R.T.J., de Cabrera, S., 2002. Late Cretaceous (Campanian) carbon isotope events, sea-level change and correlation of the Tethyan and Boreal realms. Palaeogeography, Palaeoclimatology, Palaeoecology 188, 215-248.

Jarvis, I., Gale, A.S., Jenkyns, H.C., Pearce, M.A., 2006. Secular variation in Late Cretaceous carbon isotopes: a new $\delta^{13} \mathrm{C}$ carbonate reference curve for the Cenomanian-Campanian (99.6-70.6 Ma). Geological Magazine 143, 561-608.

Jenkyns, H.C., 1980. Cretaceous anoxic events; from continents to oceans. Journal of the Geological Society of London 137, 171-188.

Jenkyns, H.C., 1995. Carbon-isotope stratigraphy and paleoceanographic significance of the Lower Cretaceous shallow-water carbonates of Resolution Guyot Mid-Pacific Mountains. Proceedings of the Ocean Drilling Program. Scientific Results 143, 99-104.

Jiang, M.J., 1989. Biostratigraphy and geochronology of the Eagle Ford Shale, Austin Chalk, and lower Taylor marl in Texas based on calcareous nannofossils. Unpubl. Ph.D. dissertation. Texas A\&M University, College Station, Texas, 496 pp.

Jimenez-Berrocoso, A., MacLeod, K.G., Martin, E.E., Bourbon, E., Londono, C.I., Basak, C., 2010. Nutrient trap for Late Cretaceous organic-rich black shales in the tropical North Atlantic. Geology 38, 1111-1114.

Keith, M.L., Weber, J.N., 1965. Systematic relationships between carbon and oxygen isotopes in carbonates deposited by modern corals and algae. Science 150, 498-501.

Keller, C.E., Hochuli, P.A., Weissert, H., Bernasconi, S.M., Giorgioni, M., Garcia, T.I., 2011. A volcanically induced climate warming and floral change preceded the onset of OAE1a (Early Cretaceous). Palaeogeography, Palaeoclimatology, Palaeoecology 305, 43-49.

Kennedy, W.J., Cobban, W.A., Hancock, J.M., Gale, A.S., 2005. Upper Albian and Lower Cenomanian ammonites from the Main Street Limestone, Grayson Marl and Del Rio Clay in northeast Texas. Cretaceous Research 26, 349-428.

Kleypas, J.A., Buddemeier, R.W., Archer, D., Gattuso, J.P., Langdon, C., Opdyke, B.N., 1999. Geochemical consequences of increased atmospheric carbon dioxide on coral reefs. Science 284, 181-198.

Kump, L.R., Arthur, M.A., 1999. Interpreting carbon-isotope excursions: carbonates and organic matter. Chemical Geology 161, 181-198.

Kuroda, J., Ogawa, N.O., Tanimizu, M., Coffin, M.F., Tokuyama, H., Kitazato, H., Ohkouchi, N 2007. Contemporaneous massive subaerial volcanism and Late Cretaceous Oceanic Anoxic Event 2. Earth and Planetary Science Letters 256, $211-223$.

Larson, R.L., 1991. Latest pulse of Earth: Evidence for a mid-Cretaceous superplume. Geology 19, 547-550.

Larson, R.L., Erba, E., 1999. Onset of the mid-Cretaceous greenhouse in the Barremian-Aptian: Igneous events and the biological, sedimentary, and geochemical responses. Paleoceanography 14, 663-678.

Lees, J.A., Brown, P.R., Young, J.R., 2006. Photic zone palaeoenvironments of the Kimmeridge Clay Formation (Upper Jurassic, UK) suggested by calcareous nannoplankton palaeoecology. Palaeogeography, Palaeoclimatology, Palaeoecology $235,110-134$

Lehmann, C., Osleger, D.A., Montanez, I., 2000. Sequence stratigraphy of Lower Cretaceous (Barremian-Albian) carbonate platforms of northeastern Mexico; regional and global correlations. Journal of Sedimentary Research 70, 373-391.

Lock, B.E., Peschier, L., 2006. Boquillas (Eagle Ford) upper slope sediments, West Texas; outcrop analogs for potential shale reservoirs. Transactions of the Gulf Coast Association of Geological Societies 56, 491-508.

Lock, B.E., Bases, F.S., Glaser, R.A., 2007. The Cenomanian sequence stratigraphy of central to West Texas. Transactions of the Gulf Coast Association of Geological Societies 57, 465-479.

Locklair, R., Sageman, B., Lerman, A., 2011. Marine carbon burial flux and the carbon isotope record of Late Cretaceous (Coniacian-Santonian) Oceanic Anoxic Event III. Sedimentary Geology 235, 38-49.
Locklair, R.E., Sageman, B., Anonymous, 2004. Development of a ConiacianSantonian orbital time scale and comparative estimates of primary production vs. dilution for Late Cretaceous chalk facies. Abstracts with Programs. Geological Society of America 36, 304.

Loucks, R.G., 1976. Pearsall Formation, Lower Cretaceous, south Texas: depositional facies and carbonate diagenesis and their relationship to porosity. Unpubl. Ph.D. dissertation. The University of Texas at Austin, Austin, Texas, 362 pp.

Loucks, R.G., Kerans, C., 2003. Lower Cretaceous Glen Rose 'patch reef' reservoir in the Chittim Field, Maverick County, south Texas. Transactions of the Gulf Coast Association of Geological Societies 53, 490-503.

Mehay, S., Keller, C.E., Bernasconi, S.M., Weissert, H., Erba, E., Bottini, C., Hochuli, P.A., 2009. A volcanic CO2 pulse triggered the Cretaceous Oceanic Anoxic Event 1a and a biocalcification crisis. Geology 37, 819-822.

Menegatti, A.P., Weissert, H., Brown, R.S., Tyson, R.V., Farrimond, P., Strasser, A., Caron, M., 1998. High-resolution delta (super 13) C stratigraphy through the early Aptian 'Livello Selli' of the Alpine Tethys. Paleoceanography 13, 530-545.

Millan, M.I., Weissert, H.J., Fernandez-Mendiola, P.A., Garcia-Mondejar, J., 2009. Impact of Early Aptian carbon cycle perturbations on evolution of a marine shelf system in the Basque-Cantabrian Basin (Aralar, N Spain). Earth and Planetary Science Letters 287, 392-401.

Miller, K.G., Sugarman, P.J., Browning, J.V., Kominz, M.A., Olsson, R.K., Feigenson, M.D., Hernandez, J.C., 2004. Upper Cretaceous sequences and sealevel history, New Jersey Coastal Plain. Geological Society of America Bulletin $116,368-393$.

Moldovanyi, E.P., Lohmann, K.C., 1984. Isotopic and petrographic record of phreatic diagenesis: Lower Cretaceous Sligo and Cupido formations. Journal of Sedimentary Petrology 54, 972-985.

Montoya-Pino, C., Weyer, S., Anbar, A.D., Pross, J., Oschmann, W., Van de Schootbrugge, B., Arz, H.W., 2010. Global enhancement of ocean anoxia during Oceanic Anoxic Event 2: a quantitative approach using U isotopes. Geology 38, 315-318.

Moore, C.H., 2001. Carbonate reservoirs, porosity evolution and diagenesis in a sequence stratigraphic framework. Elsevier, New York, $444 \mathrm{pp}$.

Mort, H.P., Adatte, T., Follmi, K.B., Keller, G., Steinmann, P., Matera, V., Berner, Z., Stuben, D., 2007. Phosphorus and the roles of productivity and nutrient recycling during oceanic anoxic event 2. Geology 35, 483-486.

Moullade, M., Kuhnt, W., Bergen, J.A., Masse, J.P., Tronchetti, G., 1998. Correlation of biostratigraphic and stable isotope events in the Aptian historical stratotype of La Bedoule (southeast France). Comptes Rendus de l'Academie des Sciences, Serie II. Sciences de la Terre et des Planètes 327, 693-698.

Parente, M., Frijia, G. Di Lucia, M. Jenkyns, H.C. Woodfine, R.G., Baroncini, F., 2008 Stepwise extinction of larger foraminifers at the Cenomanian-Turonian boundary: a shallow-water perspective on nutrient fluctuations during Oceanic Anoxic Event 2 (Bonarelli Event). Geology 36, 715-718.

Patterson, W.P., Walter, L.M., 1994. Depletion of ${ }^{13} \mathrm{C}$ in seawater $\{$ Sigma $\}$ C02 on modern carbonate platforms: significance for the carbon isotopic record of carbonates. Geology 22, 885-888.

Perkins, B.F., 1974. Paleoecology of a rudist reef complex in the Comanche Cretaceous Glen Rose Limestone of central Texas. Geoscience and Man 8, 131-173.

Phelps, R.M., Kerans, C., Loucks, R.G., Da Gama, R.O.B.P., Jeremiah, J., Hull, D., 2014. Oceanographic and eustatic control of carbonate platform evolution and sequence stratigraphy on the Cretaceous (Valanginian-Campanian) passive margin, northern Gulf of Mexico. Sedimentology 61, 461-496.

Pratt, L.M., Arthur, M.A., Dean, W.E., Scholle, P.A., 1984. Paleoceanographic cycles and events during the Late Cretaceous in the Western Interior Seaway. In: Caldwell, W.G.E., Kauffman, E.G. (Eds.), Cretaceous evolution of the Western Interior Basin of North America. Geological Society of Canada, Special Paper 39, pp. 333-353.

Prezbindowski, D.R., 1981. Carbonate rock-water diagenesis Lower Cretaceous, Stuart City trend, south Texas. Unpubl. Ph.D. dissertation. University of Texas at Austin, Austin, Texas, 236 pp.

Price, G.D., 2003. New constraints upon isotope variation during the Early Cretaceous (Barremian-Cenomanian) from the Pacific Ocean. Geological Magazine $140,513-522$.

Rameil, N., Immenhauser, A., Warrlich, G., Hillgartner, H., Droste, H.J. 2010. Morphological patterns of Aptian Lithocodium-Bacinella geobodies: relation to environment and scale. Sedimentology 57, 883-911.

Riebesell, U., Zondervan, I., Rost, B., Tortell, P.D., Zeebe, R.E., Morel, F.M., 2000. Reduced calcification of marine plankton in response to increased atmospheric $\mathrm{pCO}_{2}$. Nature (London) 407, 364-367.

Roehl, U., Ogg, J.G., 1996. Aptian-Albian sea level history from guyots in the western Pacific. Paleoceanography 11, 595-624.

Roth, P.H., 1978. Cretaceous nannoplankton biostratigraphy and oceanography of the northwestern Atlantic Ocean. Initial Reports of the Deep Sea Drilling Project 44, 731-759.

Rose, P.R., 1972. Edwards Group, surface and subsurface, central Texas. Texas Bureau of Economic Geology Report of Investigations 74. The University of Texas at Austin, Austin, Texas, 198 pp.

Sahagian, D., Pinous, O., Olferiev, A., Zakharov, V., 1996. Eustatic curve for the Middle Jurassic-Cretaceous based on Russian Platform and Siberian stratigraphy: zonal resolution. American Association of Petroleum Geologists Bulletin 80, 1433-1458.

Salvador, A. 1991a. Origin and development of the Gulf of Mexico Basin. In: Salvador, A. (Ed.), The geology of North America. Geological Society of America, Boulder, Colorado, pp. 389-444. 
Salvador, A., 1991b. Triassic-Jurassic. In: Salvador, A. (Ed.), The geology of North America. Geological Society of America, Boulder, Colorado, pp. 131-180.

Sawyer, D.S., Buffler, R.T., Pilger Jr., R.H., 1991. The crust under the Gulf of Mexico Basin. In: Salvador, A. (Ed.), The geology of North America. Geological Society of America, Boulder, Colorado, pp. 53-72.

Schlanger, S.O., Jenkyns, H.C., 1976. Cretaceous oceanic anoxic events; causes and consequences. Geologie en Mijnbouw 55, 179-184.

Scholle, P.A., Arthur, M.A., 1980. Carbon isotope fluctuations in Cretaceous pelagic limestones; potential stratigraphic and petroleum exploration tool. American Association of Petroleum Geologists Bulletin 64, 67-87.

Scott, R.W., 1990. Models and stratigraphy of Mid Cretaceous reef communities, Gulf of Mexico. SEPM Concepts in Sedimentology and Paleontology 2, 102 pp.

Scott, R.W., 1993. Cretaceous carbonate platform, U.S. Gulf Coast. In: Simo, T.J.O. Scott, R.W., Masse, J.-P. (Eds.), Cretaceous carbonate platforms. American Association of Petroluem Geologists Memoir 56, pp. 97-109.

Scott, R.W., Kerans, C., 2002. Late Albian carbonate platform chronostratigraphy, Devils River Formation cycle, West Texas. In: Skelton, P.W. (Ed.), Proceedings of Annual Rudist Biostratigraphy Congress, p. 26.

Scott, R.W., Fee, D., Magee, R., Laali, H., 1978. Epeiric depositional models for the Lower Cretaceous Washita Group; north-central Texas. Texas Bureau of Economic Geology Report of Investigations 94, 23 pp.

Scott, R.W., Benson, D.G., Morin, R.W., Shaffer, B.L., Oboh-Ikuenobe, F.E., 2002. Integrated Albian-lower Cenomanian chronostratigraphy standard, Trinity River section, Texas. In: Scott, R.W. (Ed.), GCS/SEPM Foundation Special Publications in Geology1, pp. 277-334.

Scott, R.W., Molineux, A.M., Loeser, H., Mancini, E.A., 2007. Lower Albian sequence stratigraphy and coral buildups; Glen Rose Formation, Texas, U.S.A. In: Scott, R.W. (Ed.), Cretaceous rudists and carbonate platforms: environmental feedback. Society for Sedimentary Geology, Special Publication 87, pp. 181-191.

Sinton, C.W. Duncan, R.A., 1997. Potential links between ocean plateau volcanism and global ocean anoxia at the Cenomanian-Turonian boundary. Economic Geology 92, 836-842.

Steuber, T., 1996. Stable isotope sclerochronology of rudist bivalves: growth rates and late Cretaceous seasonality. Geology 24, 315-318.

Stoll, H.M., Schrag, D.P., 2000. High-resolution stable isotope records from the Upper Cretaceous rocks of Italy and Spain: glacial episodes in a greenhouse planet? Geological Society of America Bulletin 112, 308-319.

Swart, P.K., Eberli, G.P., 2005. The nature of the $\delta^{13} \mathrm{C}$ of periplatform sediments; implications for stratigraphy and the global carbon cycle. Sedimentary Geology $175,115-129$.

Swart, P.K., Reijmer, J.J.G., Otto, R., 2009. A re-evaluation of facies on Great Bahama Bank; II, Variations in the $\delta^{13} \mathrm{C}, \delta^{18} \mathrm{O}$ and mineralogy of surface sediments. Special Publication of the International Association of Sedimentologists 41, 47-59.

Swezey, C.S., Sullivan, E.C., 2004. Stratigraphy and sedimentology of the Upper Cretaceous (Campanian) Anacacho limestone, Texas, USA. Cretaceous Research $25,473-497$.

Tejada, M.L.G., Mahoney, JJ., Neal, C.R., Duncan, R.A., Petterson, M.G., 2002. Basement geochemistry and geochronology of central Malaita, Solomon Islands, with implications for the origin and evolution of the Ontong Java Plateau. Journal of Petrology 43, 449-484.

Tejada, M.L.G., Suzuki, K., Kuroda, J., Coccioni, R., Mahoney, J.J., Naohiko, O., Sakamoto, T., Tatsumi, Y., 2009. Ontong Java Plateau eruption as a trigger for the early Aptian oceanic anoxic event. Geology 37, 855-858.

Tsikos, H., Karakitsios, V., Van Breugel, Y., Walsworth-Bell, B.E.N., Bombardiere, L., Petrizzo, M.R., Damsté, J.S.S., Schouten, S., Erba, E., Silva, I.P., Farrimond, P. Tyson, R.V., Jenkyns, H.C., 2004. Organic-carbon deposition in the Cretaceous of the Ionian Basin, NW Greece: the Paquier Event (OAE 1b) revisited. Geological Magazine 141, 401-416.

Turgeon, S.C., Creaser, R.A., 2008. Cretaceous oceanic anoxic event 2 triggered by a massive magmatic episode. Nature (London) 454, 323-326.
Tyrrell Jr., W.W., Scott, R.W., 1989. Early Cretaceous shelf margins, Vernon Parish, Louisiana. In: Bally, A.W. (Ed.), Atlas of seismic stratigraphy. AAPG Studies in Geology 27, pp. 11-17.

Vahrenkamp, V.C., 1996. Carbon isotope stratigraphy of the upper Kharaib and Shuaiba formations; implications for the Early Cretaceous evolution of the Arabian Gulf region. American Association of Petroleum Geologists Bulletin 80, 647-662.

Vahrenkamp, V.C., 2010. Chemostratigraphy of the Lower Cretaceous Shu'aiba Formation: a $\delta^{13} \mathrm{C}$ reference profile for the Aptian Stage from the southern NeoTethys Ocean. In: Van Buchem, F.S.P., Al-Husseini, M.I., Maurer, F., Droste, H.J (Eds.), Barremian-Aptian stratigraphy and hydrocarbon habitat of the eastern Arabian Plate. GeoArabia, Special Publication 4, pp. 107-138.

Vahrenkamp, V.C., 2013. Carbon-isotope signatures of Albian to Cenomanian (Cretaceous) shelf carbonates of the Natih Formation, Sultanate of Oman. GeoArabia 18, 65-82.

Van Buchem, F.S.P., Al-Husseini, M.I., Maurer, F., Droste, H.J., Yose, L.A., 2010 Sequence-stratigraphic synthesis of the Barremian-Aptian of the eastern Arabian Plate and implications for the petroleum habitat. In: Van Buchem, F.S.P., Al-Husseini, M.I., Maurer, F., Droste, H.J. (Eds.), Barremian-Aptian stratigraphy and hydrocarbon habitat of the eastern Arabian Plate. GeoArabia, Special Publication 4, pp. 9-48.

Waite, L.E., Scott, R.W., Kerans, C., 2007. Middle Albian age of the regional dense marker bed of the Edwards Group, Pawnee Field, south-central Texas. Transactions of the Gulf Coast Association of Geological Societies 57, 759-774.

Weber, J.N., 1965. Fractionation of stable isotopes of O and C in marine calcareous organisms. Geochemica et Cosmochimica Acta 30, 681-703.

Weissert, H., 1989. C-isotope stratigraphy, a monitor of paleoenvironmental change: a case study from the Early Cretaceous. Surveys in Geophysics 10, 1-61.

Weissert, H., Erba, E., 2004. Volcanism, CO2 and palaeoclimate: a Late Jurassic-Early Cretaceous carbon and oxygen isotope record. Journal of the Geological Society 161, 695-702.

Weissert, H., Lini, A., Foellmi, K.B., Kuhn, O., 1998. Correlation of Early Cretaceous carbon isotope stratigraphy and platform drowning events; a possible link? Palaeogeography, Palaeoclimatology. Palaeoecology 137, 189-203.

Wendler, I., Wendler, J., Graefe, K.U., Lehmann, J., Willems, H., 2009. Turonian to Santonian carbon isotope data from the Tethys Himalaya, southern Tibet. Cretaceous Research 30, 961-979.

Wilson, P.A., Norris, R.D., 2001. Warm tropical ocean surface and global anoxia during the Mid-Cretaceous period. Nature (London) 412, 425-428.

Winker, C.D., Buffler, R.T., 1988. Paleogeographic evolution of early deep-water Gulf of Mexico and margins, Jurassic to Middle Cretaceous (Comanchean). American Association of Petroleum Geologists Bulletin 72, 318-346.

Wissler, L., Weissert, H., Buonocunto, F.P., Ferreri, V., D'Argenio, B., 2004. Calibration of the Early Cretaceous time scale: a combined chemostratigraphic and cyclostratigraphic approach to the Barremian-Aptian interval, Campania Apennines and southern Alps (Italy). In: D'Argenio, B., Fischer, A.G., Silva, I.P., Weissert, H. Ferreri, V. (Eds.), Cyclostratigraphy: approaches and case histories. Society for Sedimentary Geology, Tulsa, pp. 123-133.

Wissler, L., Funk, H., Weissert, H., 2003. Response of Early Cretaceous carbonate platforms to changes in atmospheric carbon dioxide levels. Palaeogeography, Palaeoclimatology, Palaeoecology 200, 187-205.

Young, K., 1986. Cretaceous, marine inundations of the San Marcos Platform, Texas. Cretaceous Research 7, 117-140.

\section{Appendix A. Supplementary data}

Supplementary data related to this article can be found at http://dx.doi.org/10. 1016/j.cretres.2014.09.002. 